\title{
Tidal Flow in Selected Areas of Tampa Bey and Charlotte Harbor, Florida, 1995-96
}

By M.J. DelCharco

\section{U.S. GEOLOGICAL SURVEY}

Water-Resources Investigations Report 97-4265

Prepared in cooperation with the

Southwest Florida Water Management District

Tallahassee, Florida 1998

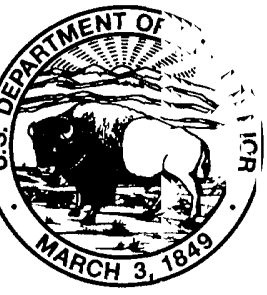




\title{
U.S. DEPARTMENT OF THE INTERIOR BRUCE BABBITT, Secretary
}

\author{
U.S. GEOLOGICAL SURVEY \\ Thomas J. Casadevall, Acting Director
}

The use of firm, trade, and brand names in this report is for identification purposes only and does not constitute endorsement by the U.S. Geological Survey.

For addtional information write to:

\section{District Chief}

U.S. Geological Survey

227 North Bronough Street, Suite 3015

Tallahassee, FL 32301
Copies of this report can be purchased from:

U.S. Geological Survey Branch of Information Services Box 25286, MS 517

Denver, CO 80225-0286 


\section{CONTENTS}

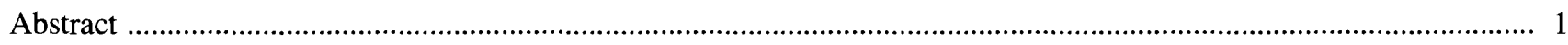

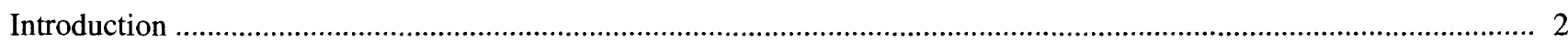

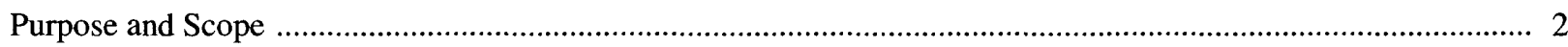

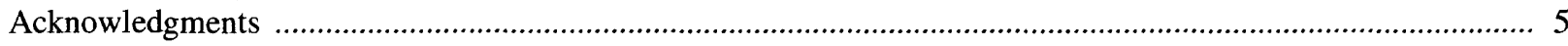

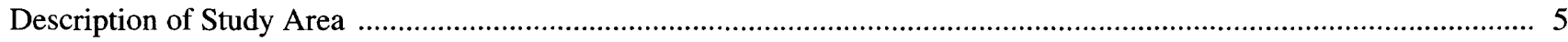

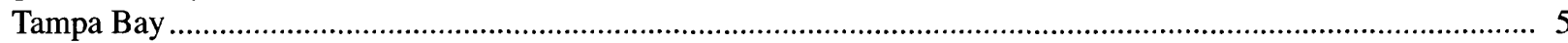

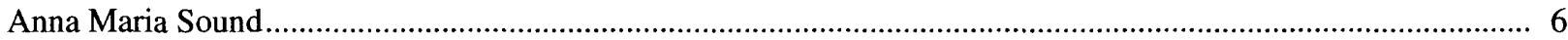

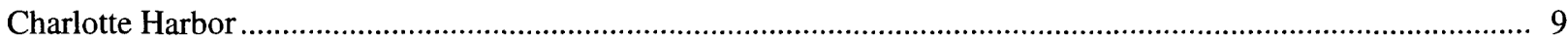

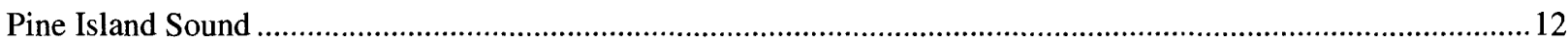

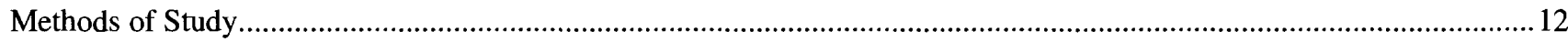

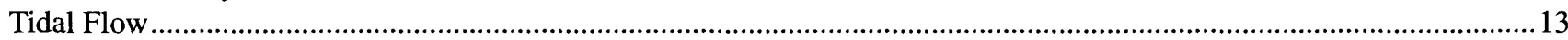

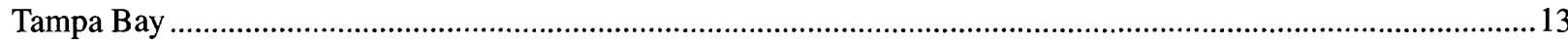

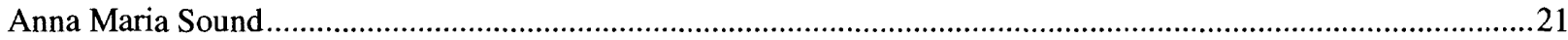

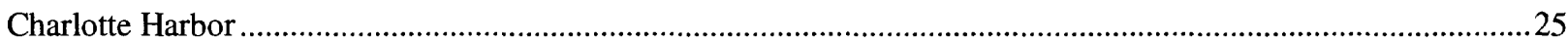

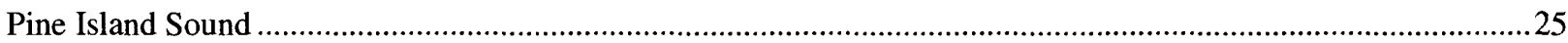

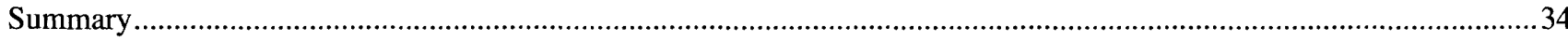

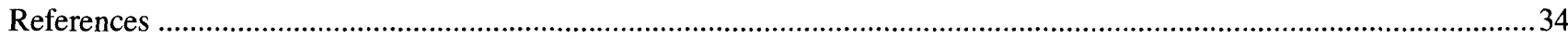

Appendix. Flow Data in Tampa Bay and Charlotte Harbor, Florida, 1995-96 ................................................................38

\section{FIGURES}

1-3. Maps showing:

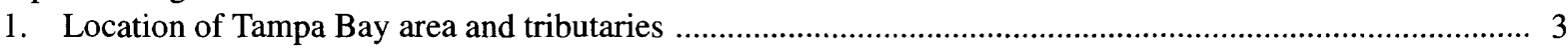

2. Location of Charlotte Harbor area and tributaries .............................................................................. 4

3. Generalized bathymetry of Tampa Bay and Anna Maria Sound, Florida,

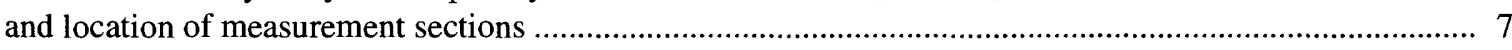

4-6. Graphs showing:

4. Cross-section depths at the mouth of Tampa Bay, Florida ................................................................ 8

5. Sum of daily mean inflow from gaged locations to Tampa Bay, Florida, 1995-96 …................................. 8

6. Cross-section depths in Anna Maria Sound, Florida ............................................................................. 9

7. Map showing generalized bathymetry of Charlotte Harbor and Pine Island Sound, Florida, and location of

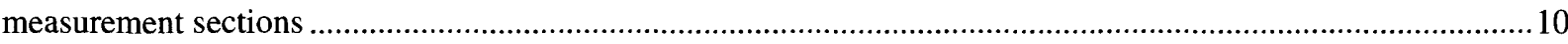

8-11. Graphs showing:

8. Cross-section depths at the mouth of Charlotte Harbor, Florida .............................................................11

9. Sum of daily mean inflow from gaged locations to Charlotte Harbor, Florida, 1995-96 ..............................11

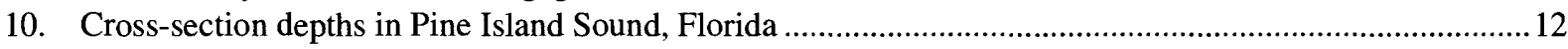

11. Flow and tidal elevation at the mouth of Tampa Bay, Florida........................................................... 14

12. Map showing flow patterns along the measurement section A-A' at the mouth of Tampa Bay,

Florida, November 6, 1996.

13-14. Diagram showing:

13. Velocities at the mouth of Tampa Bay, Florida, for ebb, flood, and near slack flows ...................................19

14. Velocities at the mouth of Tampa Bay, Florida, for stratified flows and slightly stratified flows ...................20

15. Graph showing flow and tidal elevation in Anna Maria Sound, Florida …......................................................22

16. Map showing flow patterns along the measurement section B-B' in Anna Maria Sound during simultaneous measurements at the mouth of Tampa Bay, Florida, November 6, 1996 ......................................23

17. Graph of flow and tidal elevation at the mouth of Charlotte Harbor, Florida .......................................................26 
18. Map showing flow patterns along the measurement section $\mathrm{C}^{-} \mathrm{C}^{\prime}$ at the mouth of Charlotte Harbor, Florida, July 9, 1996

19. Diagram showing velocities at the mouth of Charlotte Harbor, Florida, for ebb, flood, and near slack flows ........ 31

20. Map showing flow patterns along measurement sections D-D', E-E', and F-F' in Pine Island Sound during simultaneous measurements at the mouth of Charlotte Harbor, Florida

Table

1. Physical characteristics of Tampa Bay and Charlotte Harbor

6

CONVERSION FACTORS, VERTICAL DATUM, AND ADDITIONAL ABBREVIATIONS

\begin{tabular}{rll}
\hline Multiply inch-pound unit & By & To obtain \\
\hline inch $(\mathrm{in})$. & 25.4 & millimeter \\
foot $(\mathrm{ft})$ & 0.3048 & meter \\
mile $(\mathrm{mi})$ & 1.609 & kilometer \\
miles per hour $(\mathrm{mi} / \mathrm{h})$ & 1.609 & kilometers per hour \\
square mile $\left(\mathrm{mi}^{2}\right)$ & 2.590 & square kilometer \\
cubic foot per second $\left(\mathrm{ft}^{3} / \mathrm{s}\right)$ & 0.02832 & cubic meter per second \\
\hline
\end{tabular}

Temperature can be converted between degrees Fahrenheit $\left({ }^{\circ} \mathrm{F}\right)$ and degrees Celsius $\left({ }^{\circ} \mathrm{C}\right)$ as follows:

$$
\begin{gathered}
{ }^{\circ} \mathrm{F}=9 / 5\left({ }^{\circ} \mathrm{C}\right)+32 \\
{ }^{\circ} \mathrm{C}=5 / 9\left({ }^{\circ} \mathrm{F}-32\right)
\end{gathered}
$$

Sea level: In this report, "sea level" refers to the National Geodetic Vertical Datum of 1929 (NGVD of 1929)--a geodetic datum derived from a general adjustment of the first-order level nets of the United States and Canada, formerly called Sea Level Datum of 1929.

Mean lower low water ( $m l l w$ ): A tidal datum calculated from the arithmetic mean of lower low water heights of a mixed tide observed over a specific 19-year Metonic cycle (the National Tidal Datum Epoch).

\section{ADDITIONAL ABBREVIATIONS}

$\begin{array}{ll}\text { ADCP } & \text { acoustic Doppler current profiler } \\ \mathrm{kHz} & \text { kilohertz } \\ \text { NOAA } & \text { National Oceanic and Atmospheric Administration } \\ \text { PVC } & \text { polyvinyl chloride } \\ \text { USGS } & \text { U.S. Geological Survey }\end{array}$




\title{
Tidal Flow in Selected Areas of Tampa Bay and Charlotte Harbor, Florida, 1995-96
}

\author{
By Michael J. DelCharco
}

\section{Abstract}

Until recently, flow between the Gulf of Mexico and the two largest estuaries in Florida, Tampa Bay and Charlotte Harbor, had been studied using limited field data sets. Because many regulatory and management decisions are based on circulation patterns and flow, it is essential to understand and expand the knowledge of estuarine flows. The cost and complexities of field measurements had limited the direct measurement of flow until the development of the broad-band acoustic Doppler current profiler. This meter improves the spatial and temporal measurements of flow velocities, compared to standard pointvelocity techniques, and allows for more accurate calculations of flow.

Reconnaissance measurements of flow in Tampa Bay and Charlotte Harbor began in January 1995 and led to the selection of measurement locations at the mouth of Tampa Bay, the north end of Anna Maria Sound, the mouth of Boca Grande Pass, and the north end of Pine Island Sound. During a 2-year period, 232 flow measurements were made at these locations. Riverine and tributary flows to Tampa Bay and Charlotte Harbor were recorded and used to examine freshwater inflow volumes to the systems. Continuous measurements of tidal elevation and wind also were made during the flow measurements.

Flow measurements at the mouth of Tampa Bay ranged from 1,260,000 cubic feet per second for an ebb flow to $-954,000$ cubic feet per second for a flood flow, with the largest percentages of flow occurring in the Egmont Channel, Southwest Channel, and Passage Key Inlet. Flow between
Tampa Bay and Anna Maria Sound was small, typically less than 1 percent of the flow at the mouth of Tampa Bay. Flow measurements for this study were of the same magnitude and range as those previously made in the bay, but of greater detail, allowing for a better understanding of flow patterns across the mouth and in the channels. Boca Grande Pass flow measurements ranged from an ebb flow of 428,000 cubic feet per second to a flood flow of $-398,000$ cubic feet per second, with flow fairly evenly distributed across the mouth. Flows measured at Boca Grande pass were of the same magnitude and range as trose previously made using point-velocity meters. Measurements at Pine Island Sound were divided into three sections due to the size, shallow depths, and shoals present in the upper end of the sound. Flow in the western part of the sound was in the same phase as at Boca Grande Pass (flood or ebb) but carried only about 3 percent of the total flow at the pass. Flow through an area above Useppa Island moved west to east during flood flows at Boca Grande Pass and was less than 3 percent of the total flow at the pass and in the opposite direction for ebb flows. Flows measured in the natural channel east of Useppa Island were to the north during flood flows at Boca Grande Pass and in the opposite direction for ebb flows. Flows at this section were about 4 to 5 percent of the total flow at Boca Grande Pass. Measurements of flow in Pine Island Sound had not previously been made, but comparisons to numerical circulation models showed consistent flow magnitude and directions. 


\section{INTRODUCTION}

Tampa Bay and Charlotte Harbor are the two largest estuaries of Florida (figs. 1 and 2) and are vital to the Gulf of Mexico fish population, serving as nursery habitat for a variety of fish including sea trout, striped mullet, red drum, snook, mangrove snapper, and tarpon. The local economies are stimulated by the recreational and commercial use of these two estuarine systems and their ecological health is an issue of great concern. In 1995, the U.S. Geological Survey (USGS) began a cooperative study with the Southwest Florida Water Management District to measure the flow between each of the two estuarine systems and the Gulf of Mexico under a range of tidal, freshwater inflow, and wind conditions.

Scientists and water managers have sought to understand the circulation patterns within these large estuarine systems for years, but the cost and complexities associated with field measurements of tidal currents have limited field data-collection efforts. One massive data-collection effort was done in Tampa Bay by the National Oceanic and Atmospheric Administration's (NOAA) Coastal and Ocean Circulation Program in 1990 and 1991. This effort produced the largest volume of circulation measurements in NOAA'S 100-year history (Zervas, 1993). Collecting limited field data that can be used to calibrate numerical models that simulate the hydrodynamic patterns of an estuary is less expensive than collecting long-term, system-wide, hydrodynamic data (Hess, 1994). Models developed for Tampa Bay and Charlotte Harbor are scaled to cover the entire system (Goodwin, 1987, 1996; Galprin and others, 1991; Sheng and Peene, 1992; Sheng and others, 1994; Yassuda, 1996) and are calibrated using data from short-term deployments of point-velocity meters, tide gages, and/or several sets of flow measurements. Data collected during shortterm field measurements are informative, but may represent velocity and flow patterns that are applicable only to the tide, wind, and freshwater inflow characteristics during the measurement period. Also, the large scale of these numerical models may not show the detail necessary to understand the flow patterns in subareas of the systems. Multiple field measurements of flow during various combinations of tide, wind, and freshwater inflow can provide a better understanding of variations in flow than can a single set of flow measurements.
The development of the broad- $t$ and acoustic Doppler current profiler (ADCP) allows improved spatial and temporal measurements of flow in large, shallow tidal estuaries. This boat-mounted meter greatly reduces the difficulty and cost of field measurements and increases the accuracy of the data collected. The availability of a meter that can quickly measure multiple velocities at different depths is particularly useful in tidal estuaries because of the rapidly changing flow direction and flow stratification. Direct measurement of vertical velocities in the water column can provide insight about the flows in and out of estuaries.

Previously, questions regarding the flows in Tampa Bay and Charlotte Harbor were studied using numerical models. Flows between Tampa Bay and the Gulf of Mexico, Charlotte Harbor and the Gulf of Mexico, Anna Maria Sound and Tampa Bay, and Pine Island Sound and Charlotte Harbor were examined. These models have indicated the existence of large circulation gyres and significant residual flows, but only a few actual field measurements of flow have been made (Goodwin, 1987; Sheng and Peene, 1992). Discrete measurements of flow, such as th 'se made by a boat-mounted ADCP, will not reveal residual flows or gyres that, by definition, occur over lc ng temporal scales (days, weeks or longer). However, these measurements can document flow under a variety of flow conditions. Flow measurements made at various freshwater inflows, tidal conditions, and wind conditions provide a better understanding of seasonal variations on flow.

\section{Purpose and Scope}

This report presents the results of a study designed to measure and describe flow in selected areas of Tampa Bay and Charlotte Harbor. A total of 232 measurements of flow were made at the mouth of each estuary and within Anna Maria and Pine Island Sounds. Data collection included measuring the flows into (flood) and out of (ebb) each estuary and sound under a range of tidal elevation, wind, and freshwater inflow conditions. Measurements of tidal elevation (water-surface elevation) and wind magnitude and direction were made while flow data were being collected. Freshwater inflow data from established USGS gaging sites were used to quantify freshwater inflow. 


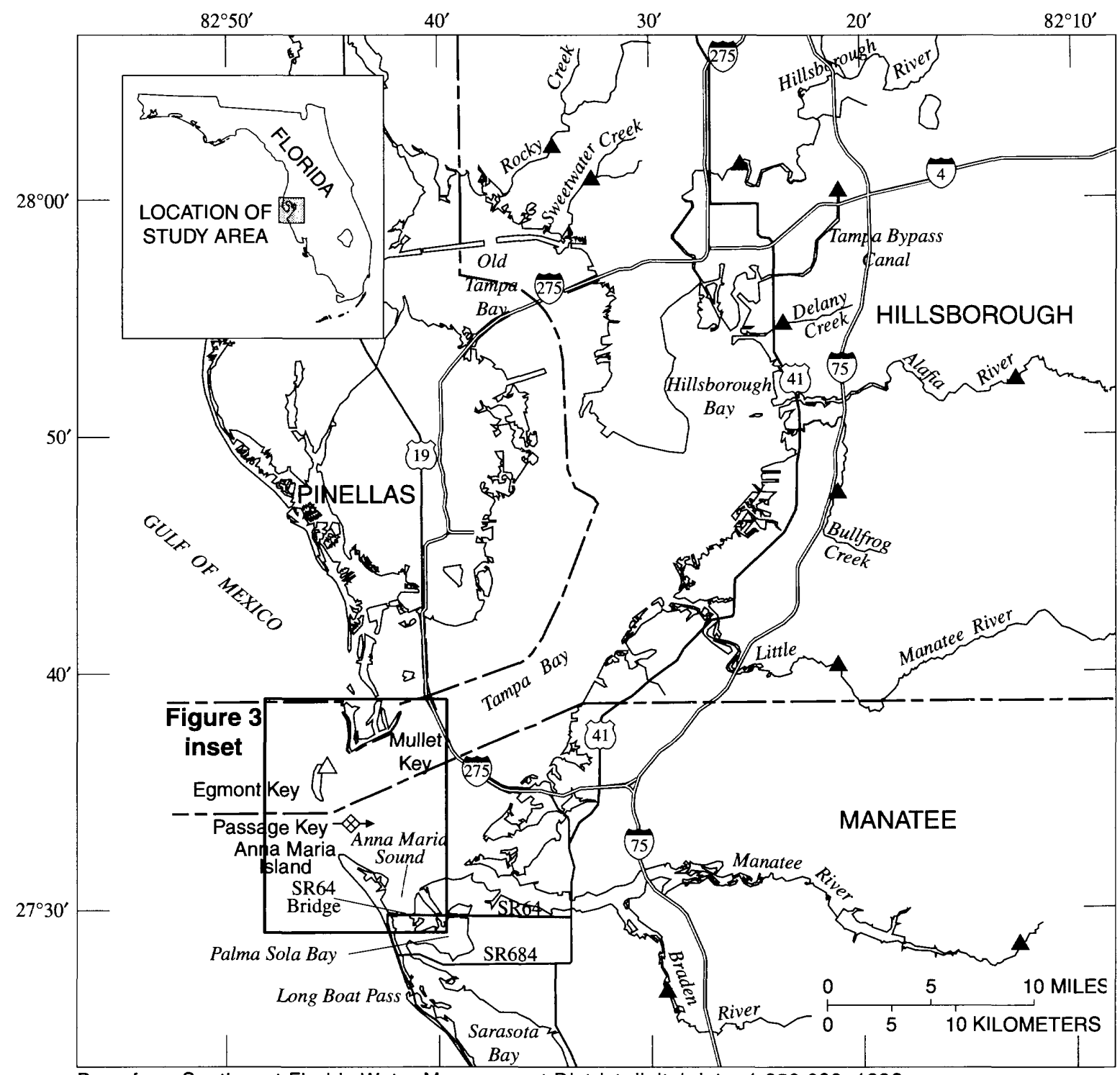

Base from Southwest Florida Water Management District digital data, 1:250,000, 1992

Albers Equal-Area Conic projection

Standard Parallels $29^{\circ} 30^{\prime}$ and $45^{\circ} 30^{\prime}$, central meridian $-83^{\circ} 00^{\prime}$

\section{EXPLANATION}

A Continuous-record gaging station

$\triangle$ Temporary tidal-elevation measurement station

$\Leftrightarrow$ Temporary wind measurement station

Figure 1. Location of Tampa Bay area and tributaries. 


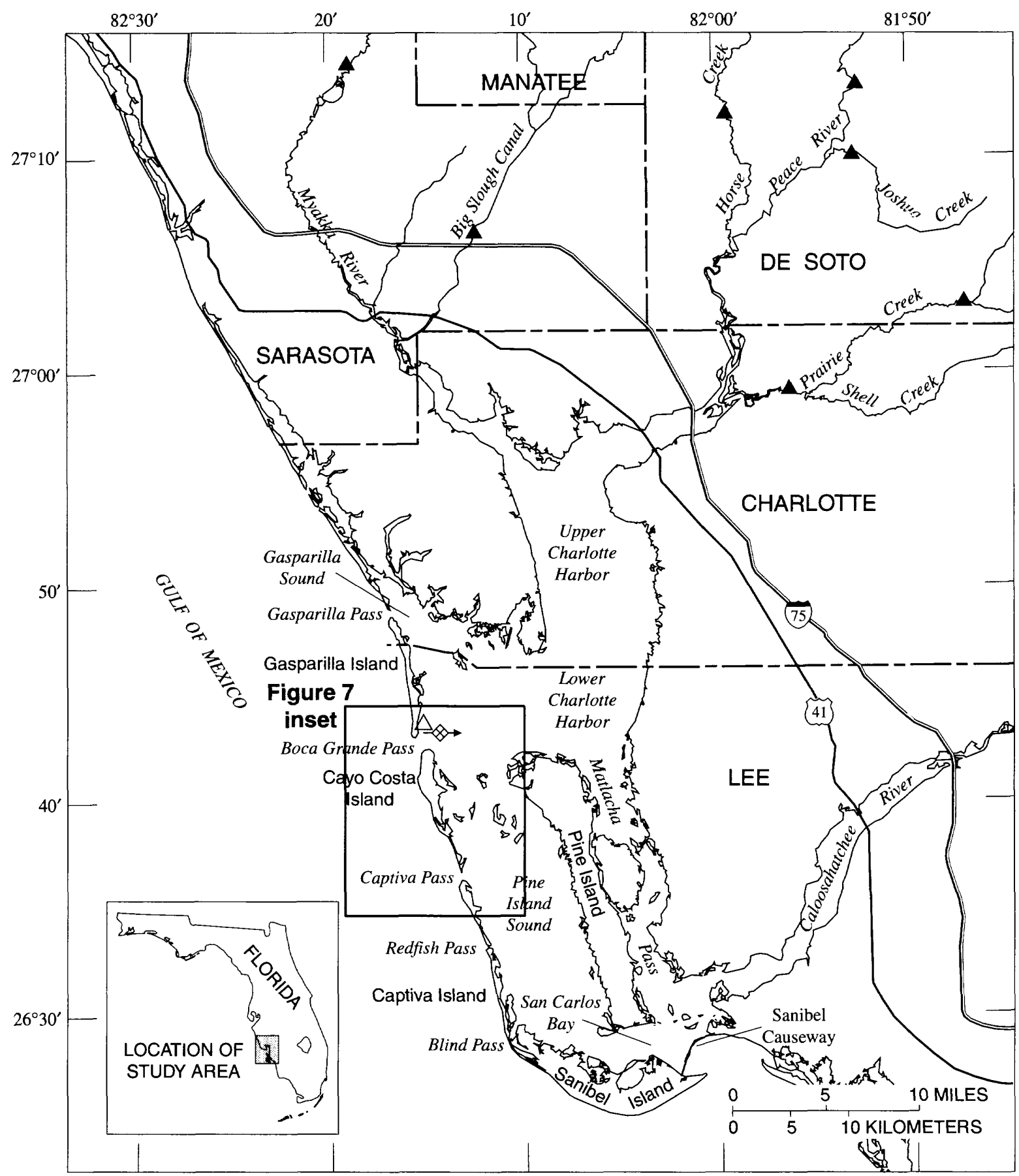

Base from Southwest Florida Water Management District digital data, 1:250,000, 1992

Albers Equal-Area Conic projection

Standard Parallels $29^{\circ} 30^{\prime}$ and $45^{\circ} 30^{\prime}$, central meridian $-83^{\circ} 00^{\prime}$

\section{EXPLANATION}

$\triangle$ Continuous-record gaging station

$\triangle$ Temporary tidal-elevation measurement station

$\rightarrow$ Temporary wind measurement station

Figure 2. Location of Charlotte Harbor area and tributaries. 
Reconnaissance measurements began in January 1995 to identify good measuring sections for each site. Measurements were made for four to five different tidal, freshwater inflow, and wind conditions at each cross section during the 2 years of data collection. Flow measurements were made during 2-day deployments in each estuary. Results of the measurements made during this study are presented and compared to results of previous measurements and circulation model studies.

\section{Acknowledgments}

The author is grateful to the following agencies and individuals for their assistance: Peter McKinney of Boca Bay Properties for allowing the USGS to construct a gage on company property; CSX for access to their pier on Gasparilla Island; Tampa Bay Pilots Association for transportation and overnight docking facilities on Egmont Key; U.S. Fish and Wildlife Service for access to Passage Key for meteorological instrumentation; Florida Department of Environmental Protection and Park Manager Bob Baker for use of their pier and house on Egmont Key, and Ft. De Soto State Park and Ranger Paul Arbuckle for overnight boat storage.

\section{DESCRIPTION OF STUDY AREA}

Typical flow patterns near the mouths of Florida estuaries are dominated by tides, physical features, and, to a lesser extent, by freshwater inflow and wind (Goodwin, 1987, 1996; Levesque and Hammett, 1997). Freshwater inflow, which varies seasonally, affects flow patterns because of the momentum and buoyancy associated with freshwater (Day and others, 1989). In a well-mixed estuary, salinity generally increases toward the mouth of the estuary (horizontal stratification). Mixed tidal conditions (semidiurnal and diurnal) and wind direction and strength can affect flow patterns. Bidirectional flow can occur in a large estuary when flow is in opposite directions for different areas in the cross section. Stratified flow occurs when velocities are in opposite directions within the same area in the cross section, such as when surface water is flowing out while bottom water is flowing in.

\section{Tampa Bay}

Tampa Bay, the largest estuary in Florida, generally is a shallow bay with a surface area of about $347 \mathrm{mi}^{2}$ (Goodwin, 1987). The average depth of the bay is about $12 \mathrm{ft}$ (table 1); about $60 \mathrm{mi}$ of $40-\mathrm{ft}$ deep navigational channels are present in the bay (Schoellhammer, 1991). A study of flow patterns in an area of lower Hillsborough Bay determined that these channels tend to dominate flow patterns in some subareas of the bay (Levesque and Hammett, 1997). Situated on the west-central coast of Florida, the bay receives freshwater inflow from several rivers and streams (fig. 1).

Tampa Bay has a subtropical climate with an annual average temperature of about $72{ }^{\circ} \mathrm{F}$ and an annual average rainfall of about 48 in. (Zervas. 1993). Annual average wind speed is about $7.5 \mathrm{mi} / \mathrm{h} \mathrm{f}$ "om the northeast (Zervas, 1993). Spring and summer winds tend to be more southerly, whereas fall and winter winds are more easterly or northeasterly (Yass ida, 1996). Winds greater than $70 \mathrm{mi} / \mathrm{h}$ and tides greater than $5 \mathrm{ft}$ can occur as a result of summer and fall hurricanes and tropical storms. Winter storm fronts also can produce strong winds and tides.

The mouth of Tampa Bay is about 5 mi wide and has two barrier islands, Egmont and Passage Keys, that significantly affect flow patterns in the area (Goodwin, 1987). Two large channels, Egmont and Southwest, carry the majority of the flow through the mouth (fig. 3) (Goodwin, 1987; Yassuda, 1996). Passage Key Inlet is influenced by the Manatee River (fig. 1) and Anna Maria Sound (Sheng and Peene, 1992). Egmont Channel is the primary navigat:onal channel for shipping and is maintained at a dredged depth of about $50 \mathrm{ft}$ (fig. 4). The natural migration of this channel is causing the erosion of Mullet and Egmont Keys.

Flow patterns in Tampa Bay are the result of the interaction of tidal water with the bottom configuration and general shape of the bay (Goodwin, 1987). These flow patterns also are affected by winds, river inflow, nontidal variations in water elevations (storm surge), and horizontal salinity gradients (Good vin, 1987; Galprin and others, 1991; Yassuda, 1996; Zervas, 1993). The bay typically is vertically well mixed because of the shallow depths, relatively small freshwater inflows, small range of tides, and ef ${ }^{f}$ ects of wind (Goodwin, 1987; Schoellhammer, 1991; Zervas, 1993). During periods of high freshwater inflow, the bay can exhibit vertical salinity stratification, 
Table 1. Physical characteristics of Tampa Bay and Charlotte Harbor

[NA, data not available. Modified from Goodwin. 1987, 1996]

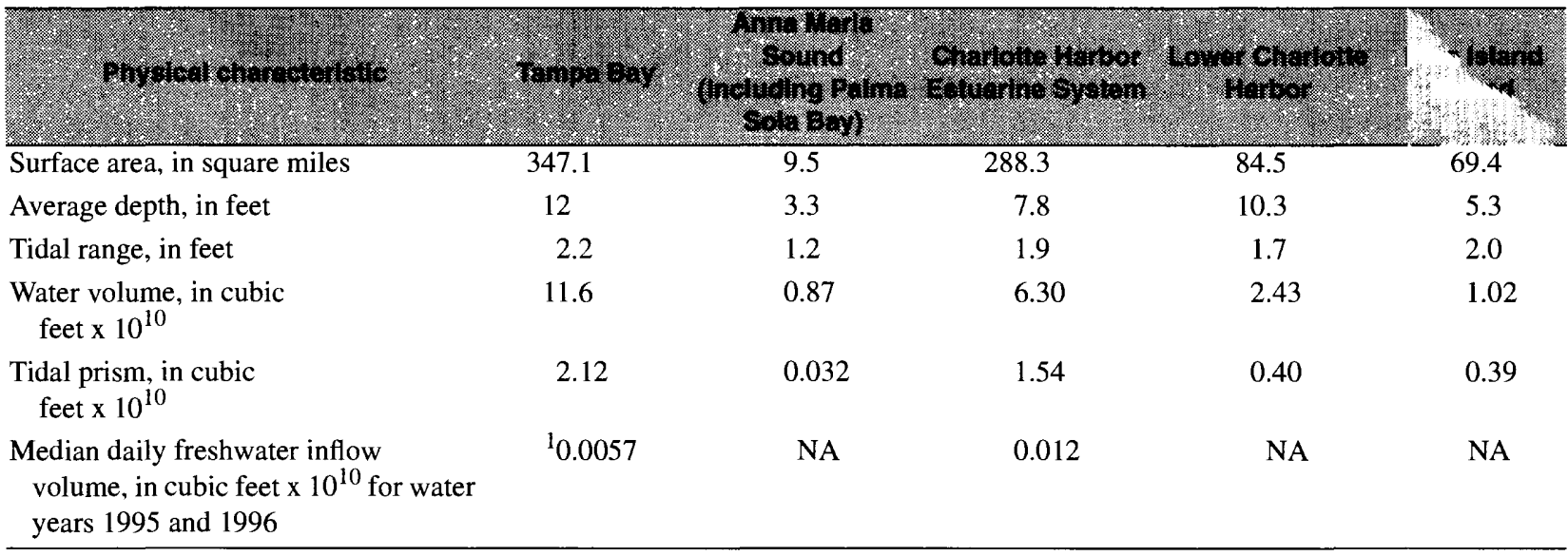

${ }^{1}$ Flows from the Tampa Bypass Canal are not included.

especially near the mouths of the larger rivers (Stoker and others, 1996). The bay also exhibits horizontal salinity gradients that can affect flow patterns (Goodwin, 1987; Wiesberg and Williams, 1991; Zervas, 1993). Tides in Tampa Bay are mixed, diurnal, and semidiurnal, with a range of about $2.2 \mathrm{ft}$ (Yassuda, 1996). The tidal range gradually increases from the mouth of the bay to its upper reaches (Zervas, 1993).

Tampa Bay does not receive large amounts of freshwater inflow (table 1), particularly when compared to the tidal prism of the bay. The tidal prism is defined as the volume of water that moves in an estuary between minimum and maximum tidal elevation. The drainage area for the basin is about $2,300 \mathrm{mi}^{2}$ and the bay receives about 70 percent of its freshwater inflow from four major rivers: the Hillsborough, the Alafia, the Little Manatee, and the Manatee Rivers (fig. 1). USGS gages on 10 rivers and tributaries in the Tampa Bay watershed measure inflow from about $1,350 \mathrm{mi}^{2}$, or about 60 percent of the total drainage area (fig. 1). The inflow data presented do not include ungaged areas of the watershed. The Hillsborough and Manatee Rivers and the Tampa Bypass Canal are regulated by dams that typically release water only during periods of high flow. Daily mean inflow from the $1,350-\mathrm{mi}^{2}$ gaged basin averages about $1,250 \mathrm{ft}^{3} / \mathrm{s}$ with a median inflow of about $493 \mathrm{ft}^{3} / \mathrm{s}$ (Coffin and Fletcher, 1996) for the period of record through 1996 for all inflow sites except the Tampa Bypass Canal. Mean flows in west-central Florida tend to be skewed because of infrequent high flows; therefore, median flows tend to be more representative of typical flow conditions. For water years
1995 and 1996, the median daily inflow to Tampa Bay for all the inflow sites was $657 \mathrm{ft}^{3} / \mathrm{s}$. Tre peak monthly inflow for the 2-year study occurred in August 1995 (fig. 5). Total inflows into the system a re shown because salinity stratification occurs when the total amount of freshwater inflow to the system is greatest. The median daily freshwater inflow volume (for water years 1995 and 1996) was less than 0.3 percent of the tidal prism. Physical characteristics of Tampa Bay and Charlotte Harbor are presented in table 1.

Stoker and others (1996) documanted the decrease in freshwater inflows to Hillshorough Bay from the Alafia and Hillsborough Rivers and Sulphur Springs and noted that the decreasing flow trends began in the early 1960's. The decrease of freshwater inflows to the bay is of concern to bay managers because of the effects these decreases have on water quality and tidal circulation (Browder, 1991; Clark, 1991; Johansson, 1991; Stowers, 1991; Zarbock, 1991).

\section{Anna Maria Sound}

Anna Maria Sound is about $4 \mathrm{mi}$ long from north to south and about $1.5 \mathrm{mi}$ wide at its mouth at Tampa Bay (figs. 1 and 3). Two constrictions, Anna Maria Island Bridge (State Road 64) and Cortez Road Bridge (State Road 684), reduce the width to about $0.5 \mathrm{mi}$ (fig. 1). Palma Sola Bay is a $4.7-\mathrm{mi}^{2}$ bay on the east side of Anna Maria Sound. The sound adjoins Sarasota Bay near the entrance of Long Boat Pass (fig. 1). The Intracoastal Waterway is a dredged channel about $10 \mathrm{ft}$ deep and about $200 \mathrm{ft}$ wide that 


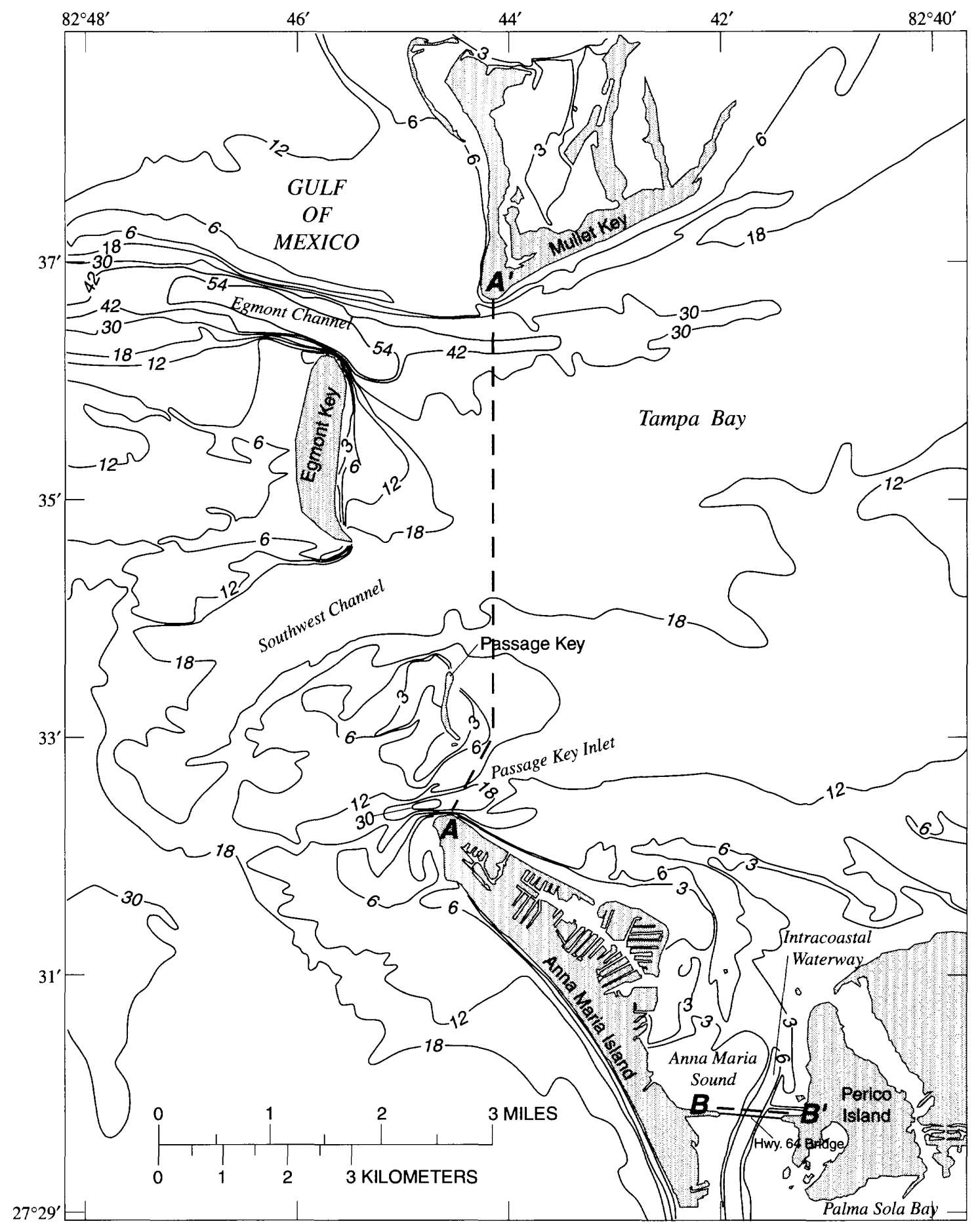

\section{EXPLANATION}

\section{- 18- BATHYMETRIC CONTOUR - - Depth \\ in feet below mean lower low water. \\ Contour intervals 3,6 , and 12 feet. \\ $\boldsymbol{A}--\boldsymbol{A}^{\prime}$ Measurement section}

Figure 3. Generalized bathymetry of Tampa Bay and Anna Maria Sound, Florida, and location of measurement sections. 


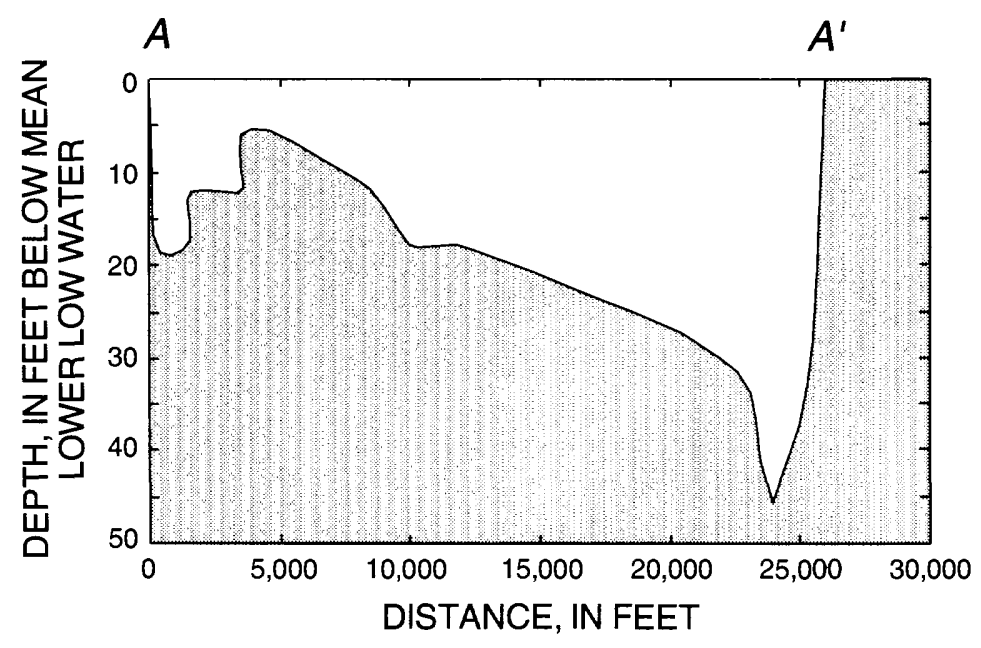

Figure 4. Cross-section depths at the mouth of Tampa Bay, Florida. (Line of section A-A' shown in figure 3.)

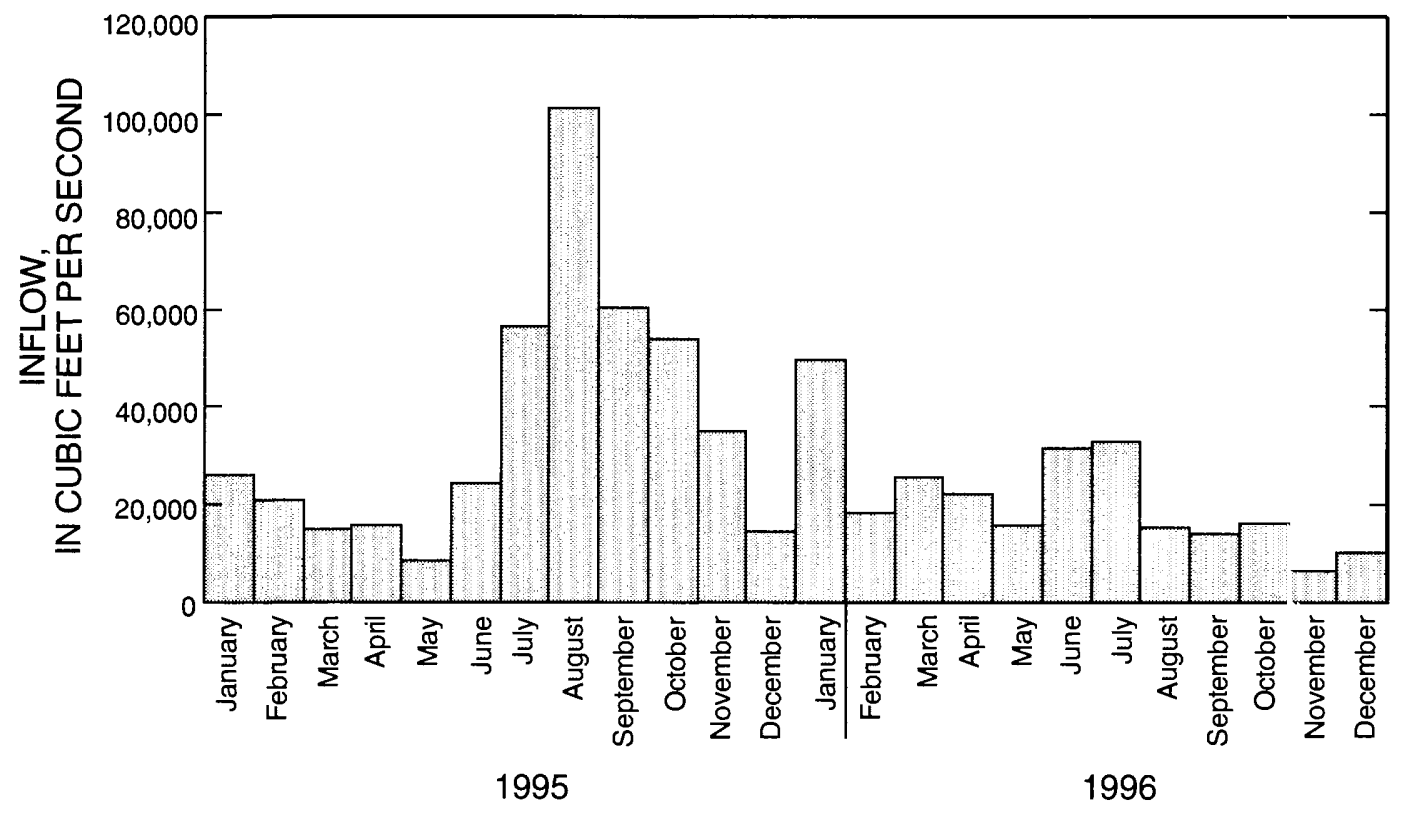

Figure 5. Sum of daily mean inflow from gaged locations to Tampa Bay, Florida, 1995-96.

runs through the sound into Sarasota Bay (fig. 3). Flow measurements for Anna Maria Sound were made in a navigational channel parallel to the State Road 64 bridge on the north side (fig. 3). This channel extends from bank to bank and has depths sufficiently deep for
ADCP measurements (fig. 6). The gereralized bathymetry in fig. 3 does not accurately show the bathymetry as measured during flow measurements. For this reason the depth data measured during flow measurements are presented in fig. 6 . 


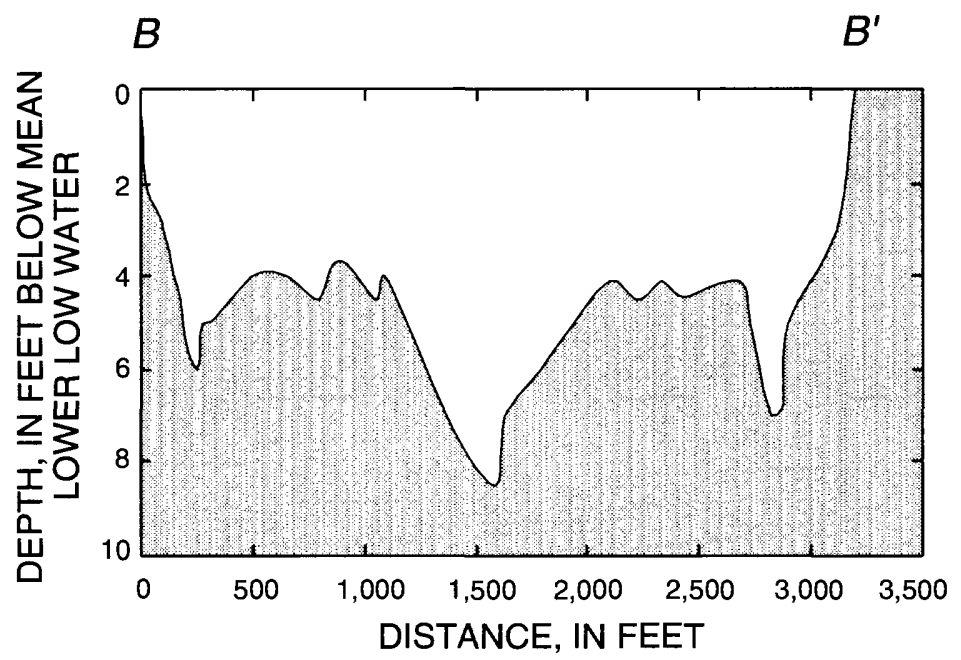

Figure 6. Cross-section depths in Anna Maria Sound, Florida. (Line of section B-B' shown in figure 3 .)

\section{Charlotte Harbor}

Charlotte Harbor is the second largest estuary in Florida, with a total surface area of about $290 \mathrm{mi}^{2}$ (table 1) and is located about $100 \mathrm{mi}$ south of Tampa Bay on the west-central coast of Florida (fig. 2). The climate is subtropical with an annual average temperature of $72^{\circ} \mathrm{F}$ and annual average rainfall of about 52 in. (Goodwin, 1996). Annual average wind speed is about $8 \mathrm{mi} / \mathrm{h}$ from the east (U.S. Department of Commerce, 1968).

Physical features of Charlotte Harbor have a dominating effect on flow patterns within the system. Boca Grande Pass is the mouth of the harbor (fig. 7) and carries two to four times more flow than any of the other passes (Goodwin, 1996). Boca Grande Pass is about $0.8 \mathrm{mi}$ wide and about $50 \mathrm{ft}$ deep at the northern end (fig. 8). The Intracoastal Waterway, dredged to a depth of about $10 \mathrm{ft}$ and about $200 \mathrm{ft}$ wide, extends from Gasparilla Sound through Pine Island Sound and into the Caloosahatchee River (fig. 2). Goodwin (1996) defined the subareas of Charlotte Harbor as Upper and Lower Charlotte Harbor, Gasparilla Sound, Pine Island Sound, Matlacha Pass, and San Carlos Bay (fig. 2); these definitions will be used in this report. Charlotte Harbor is shallow in most areas, except the main channel through Boca Grande Pass to the mouth of the Peace River (Stoker, 1992; Goodwin, 1996). The average depth of the entire Charlotte Harbor estuarine system is about $7.8 \mathrm{ft}$. For Lower Charlotte Harbor and Pine Island Sound, the average depths are $10.3 \mathrm{ft}$ and $5.3 \mathrm{ft}$, respectively (Goodwin, 1996).
Flow patterns in Charlotte Harbor are tidally driven and also can be affected by freshwater inflow, winds, nontidal variations, and horizontal salinity gradients (Goodwin, 1996; Stoker, 1992). Tide in Charlotte Harbor are characterized as mixed, diurnal and semidiurnal, with a range of about $1.9 \mathrm{ft}$ for the entire system (table 1). Tidal characteristics in the northern and southern parts of the harbor are different because of phase lags created by the geometry of the system and passes (Goodwin, 1996). The Peace and Myakka Rivers can influence circulation patterns and salinity gradients in Upper Charlotte Harbor during periods of high freshwater inflow (Stoker, 1992). Because of the orientation of the harbor, northeastsouthwest, it is affected most strongly by winds from the west and southwest. Tropical storms, hurricanes, and winter storm fronts can create large (more than $5 \mathrm{ft}$ ) nontidal variations in water levels.

Charlotte Harbor is the receiving body of freshwater inflow from three major rivers (the Myakka, the Peace, and the Caloosahatchee) and several smaller streams (fig. 2). Total drainage area for the Charlotte Harbor basin is about 4,670 $\mathrm{mi}^{2}$ (Stoker, 1992). Average freshwater inflows to Upper Charlotte Harl or from the Peace River at Arcadia and the Myakka River near Sarasota gages are 1,075 and $251 \mathrm{ft}^{3} / \mathrm{s}$, resnectively, for their periods of record (Coffin and Fetcher, 1996). Goodwin (1996) estimated average inflows for the Peace and Myakka Rivers, including the ungaged areas, to be 2,010 and $630 \mathrm{ft}^{3} / \mathrm{s}$, respectively. Median inflows for the period of record for these sites are 465 and $78 \mathrm{ft}^{3} / \mathrm{s}$, respectively. The mean and madian 


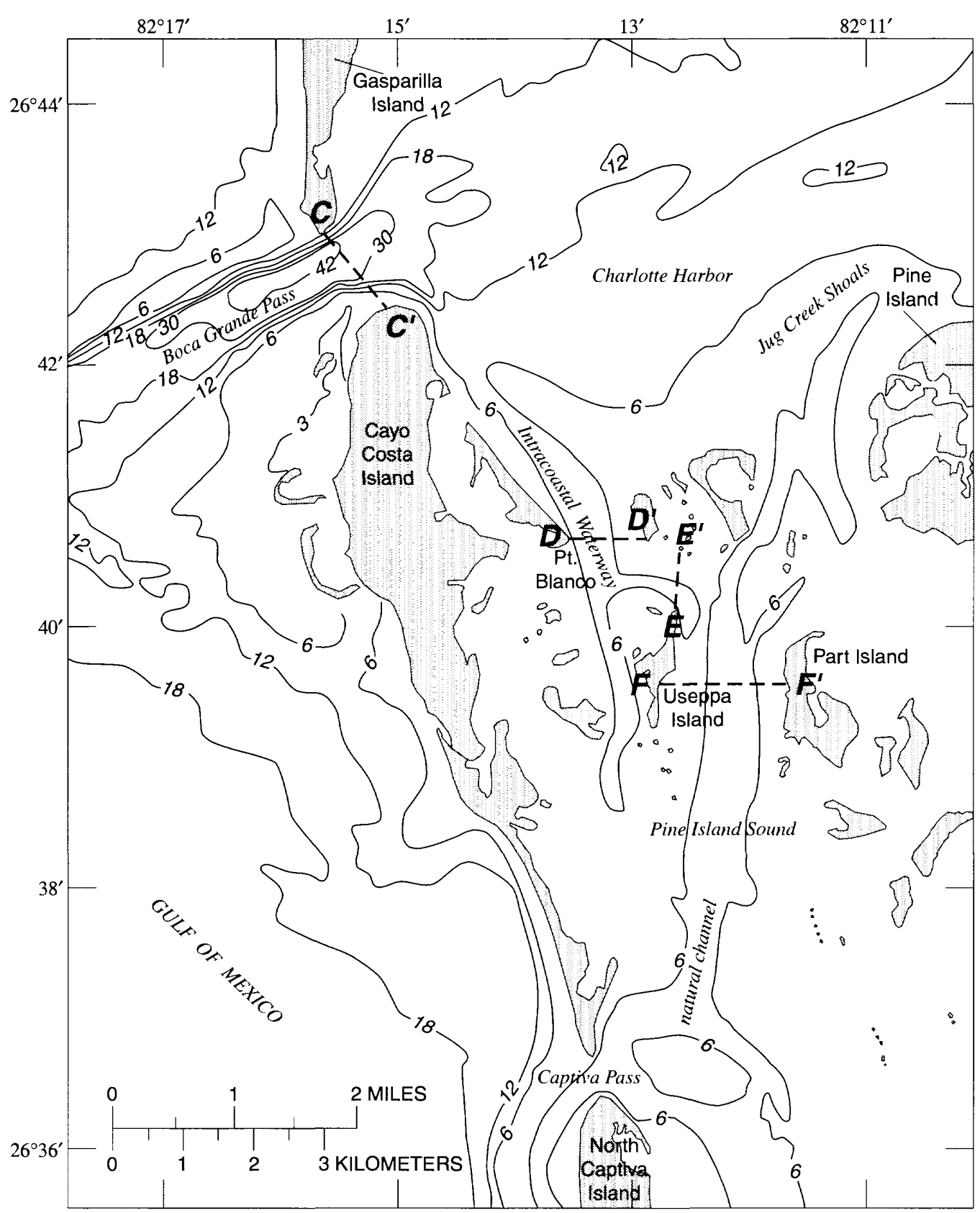

EXPLANATION

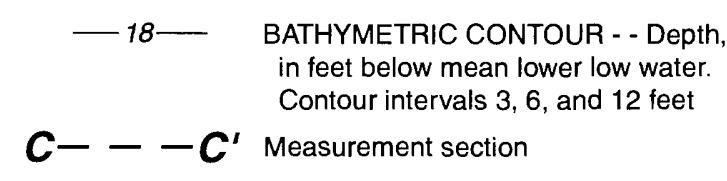

Figure 7. Generalized bathymetry of Charlotte Harbor and Pine Island Sound, Florida, and location of measurement sections. 


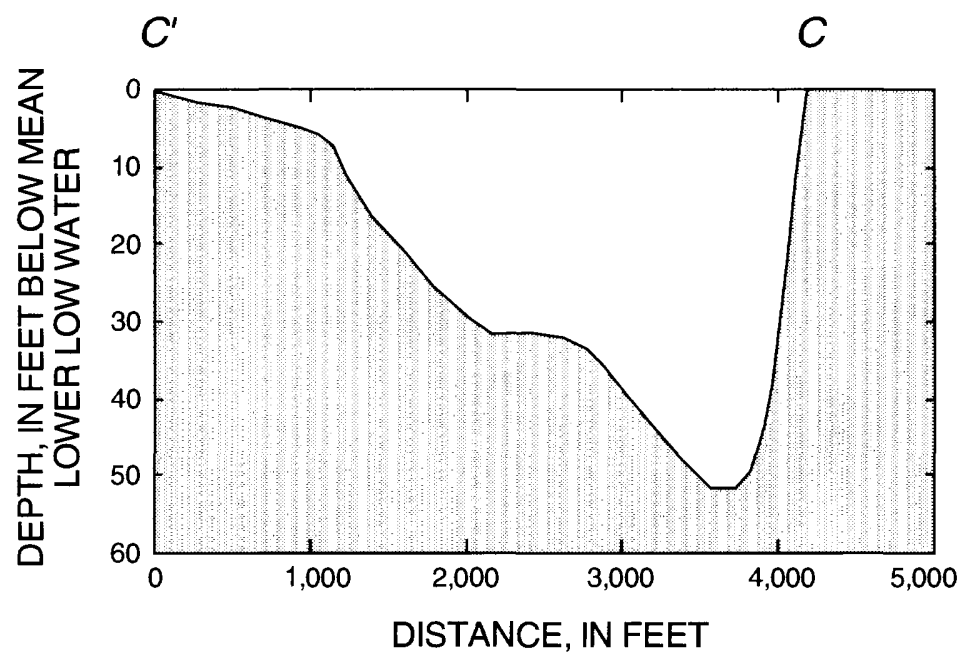

Figure 8. Cross-section depths at the mouth of Charlotte Harbor, Florida. (Line of section $\mathrm{C}-\mathrm{CC}^{\prime}$ shown in figure 7.)

daily inflows to Charlotte Harbor for all the inflow sites shown in figure 2 , were 2,980 and $1,380 \mathrm{ft}^{3} / \mathrm{s}$, respectively, for water years 1995 and 1996. The Caloosahatchee River contributes freshwater inflow at an annual average rate of about 2,000 $\mathrm{ft}^{3} / \mathrm{s}$ (Goodwin, $1996)$, but probably affects only the flow patterns in the southern part of Pine Island Sound and San Carlos Bay. Like Tampa Bay, freshwater inflow volum? is small compared to the tidal prism (table 1; fig. 9). Hammett (1990) documented flow trends in the Peace, the Myakka, and the Caloosahatchee Rivers and found a statistically significant decreasing trend only in the Peace River.

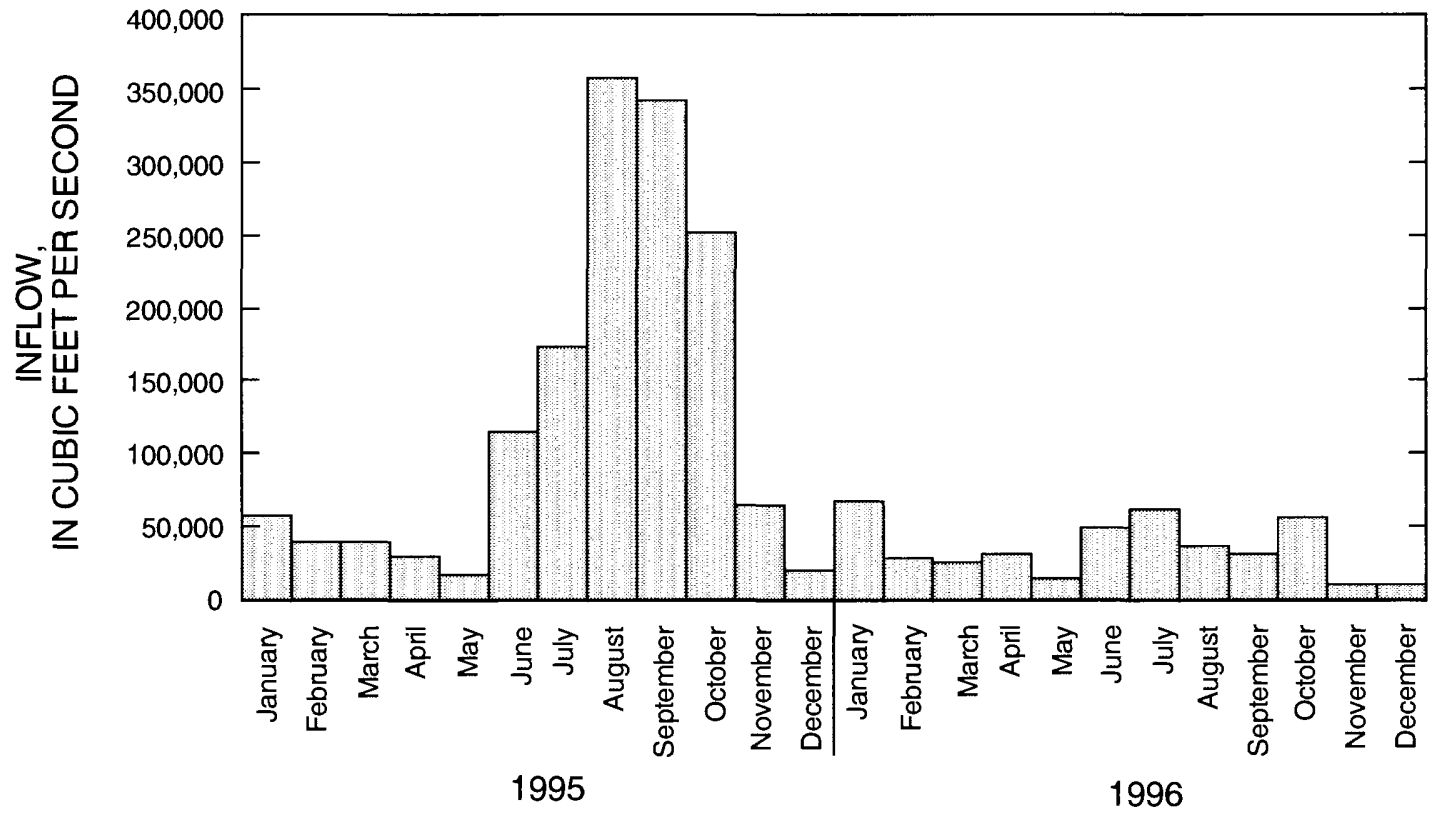

Figure 9. Sum of daily mean inflow from gaged locations to Charlotte Harbor, Florida, 1995-96. 


\section{Pine Island Sound}

Pine Island Sound is the largest area in the southern part of Charlotte Harbor. The sound generally is shallow, averaging $5.3 \mathrm{ft}$ (table 1) in depth, with large areas less than $2 \mathrm{ft}$ deep. Productive seagrass beds in these shallow areas increase friction and inhibit flow. The sound also contains numerous small islands and shoals that influence flow patterns. The northern part of the sound is about $4.5 \mathrm{mi}$ wide, but flow through the sound is restricted by several islands and shoals (fig. 7). The deepest areas of the sound are the Intracoastal Waterway, a dredged navigational channel that runs east to west just north of Useppa Island, and a natural channel that extends from Captiva Pass to the northwest end of $F$ 'ne Island. Three measurement sections (sections D-D', E-E', and F-F') (fig. 7) were used to measure flow (fig. 10).

\section{METHODS OF STUDY}

Measurements of vertical velocity profiles were collected and used to calculate flow unter various tidal elevations, freshwater inflows, and wind conditions.

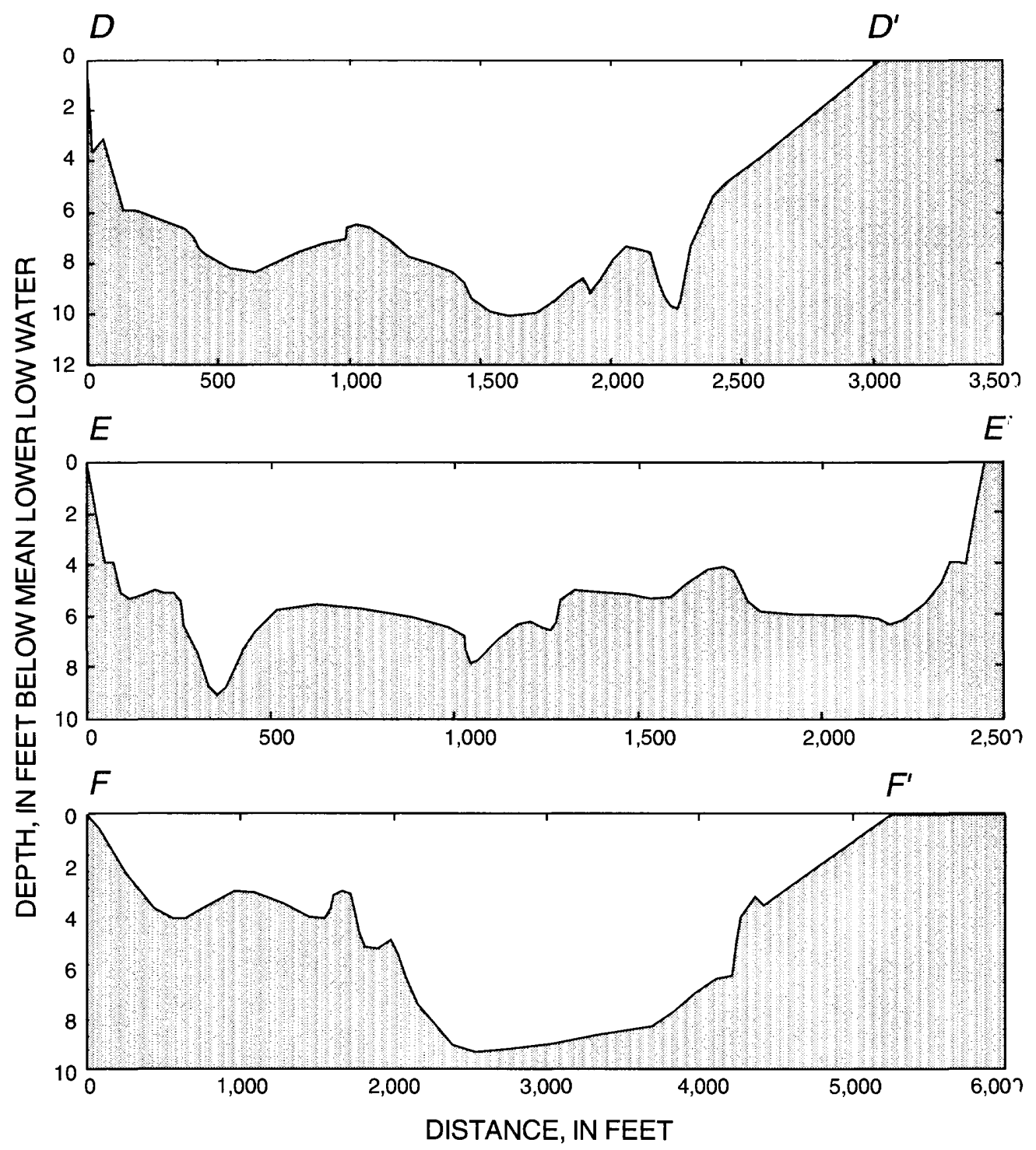

Figure 10. Cross-section depths in Pine Island Sound, Florida. (Line of sections D-D', E-E', and $F-F^{\prime}$ shown in figure 7 .) 
Flow measurements were made at the mouths of Tampa Bay and Charlotte Harbor and at sites in Pine Island Sound and Anna Maria Sound. This section describes the methods used to measure (1) flows, (2) tidal elevations and wind, and (3) freshwater inflows.

Measurements of vertical velocity profiles were made using a broad-band ADCP developed for use in water as shallow as $6 \mathrm{ft}$ deep. This meter is significantly different from the narrow-band ADCPs, such as those used by NOAA in Tampa Bay in 1990 and 1991. which required water depths greater than $15 \mathrm{ft}$. The ability to measure in shallow depths allowed flow measurements to be made across the mouths of Tampa Bay and Boca Grande Pass. Likewise, flow measurements were made in the shallow areas of Anna Maria Sound and Pine Island Sound, where depths typically are less than $10 \mathrm{ft}$. The broad-band ADCP is effective for measurements in large estuarine systems because it can measure long distances quickly. The measurement time ranged from about 20 minutes at Boca Grande Pass to about 1 hour and 20 minutes at the mouth of Tampa Bay, when traveling at a boat speed of about 3 to 5 knots. The flow measurements are considered discrete because their duration is short when compared to the tidal cycle.

Two broad-band ADCPs were deployed to measure flow, a $600 \mathrm{kHz}$ and a $1,200 \mathrm{kHz}$, using profiling software modes 4, 5, and 8 (Gordon, 1996). Typically, the $600-\mathrm{kHz}$ ADCP was used in deeper water and the $1,200-\mathrm{kHz}$ ADCP was used in shallower water. However, both meters were able to measure all the chosen measurement sections by changing the software profiling modes. Details of the technical aspects and capabilities of the broad-band ADCP are described by Gordon (1996). The technique for using a broad-band ADCP to measure flow is described by Simpson and Otlmann (1993).

During flow measurements, tidal elevation and wind direction and magnitude were recorded. Tidal elevation was recorded using a temporary continuousrecord measurement station consisting of a pressure transducer mounted inside a 2 -in PVC pipe at locations on Egmont Key at the mouth of Tampa Bay (fig. 1) and on the south end of Gasparilla Island at the mouth of Charlotte Harbor (fig. 2). Tidal elevation data are referenced to sea level. Wind magnitude and direction were recorded on Passage Key (fig. 1) and Gasparilla Island (fig. 2). Wind speed and direction data were useful in examining the short-term effects of wind on flow, such as rough water and wind-sh ear. However, in practice, the presence of a strong wind produced unfavorable measuring conditions such as too much pitch and roll of the vessel and diffic'lty navigating due to wind and waves. For these reasons, flow measurements typically were not collected during strong winds. Therefore, the data sets were generally collected under light wind conditions that probably had little effect on the flow patterns.

River and tributary flow data from long-term USGS data-collection sites were used to document freshwater inflow to the estuaries during the stidy. Reported freshwater inflows are lower than the actual inflows to Tampa Bay or Charlotte Harbor because of the ungaged areas of the basins. All USGS inflow data-collection sites are operated by the rigoro' 15 standards described by Rantz and others (1982).

\section{TIDAL FLOW}

Flow measurements at Tampa Bay and Charlotte Harbor are presented in three format: (1) plots of flow and tidal elevation, (2) plots of flow patterns along a boat path, and (3) plots of velocities measured in a cross section. Flow into the estuary or sound is called flood flow and is assigned negative values; flow out of the estuary or sound is called ebb flow and is assigned positive values. Slack flow is dofined as the time when water velocities approach zero due to either maximum or minimum tidal elevation. The 232 flow measurements made during this study are summarized in the appendix.

\section{Tampa Bay}

Forty-two measurements of flow were made at the mouth of Tampa Bay and ranged from an ebb flow of $1,260,000 \mathrm{ft}^{3} / \mathrm{s}$ to a flood flow of $-954,000 \mathrm{f}^{3} . / \mathrm{s}$. Measurements made near slack flow were as low as $11,500 \mathrm{ft}^{3} / \mathrm{s}$ and $-16,300 \mathrm{ft}^{3} / \mathrm{s}$. Slack flow at the mouth of Tampa Bay lagged maximum and minimum tidal elevation by between 2 and 3 hours (fig. 11). Only one flow measurement was made on February 2, April 12, and December 12, 1995, so these data were no* plotted.

Flow patterns at the mouth of Tampa Bay strongly reflect the influence of the three main channels and two keys (fig. 3). This influence is shown in a sequence of six flow measurements made in November 1996 (fig. 12). Horizontally and vertically averaged 
A
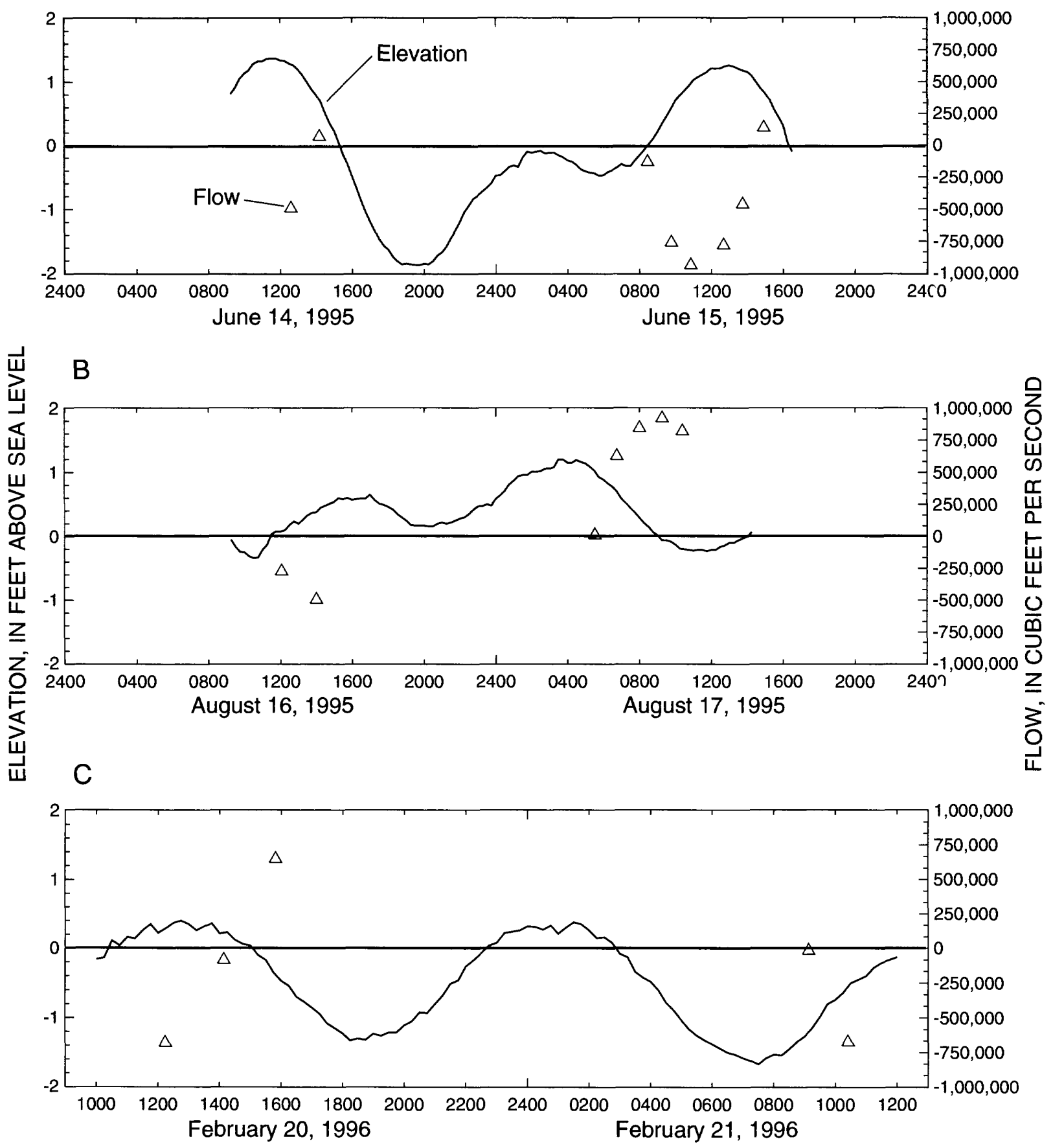

Figure 11. Flow and tidal elevation at the mouth of Tampa Bay, Florida. 


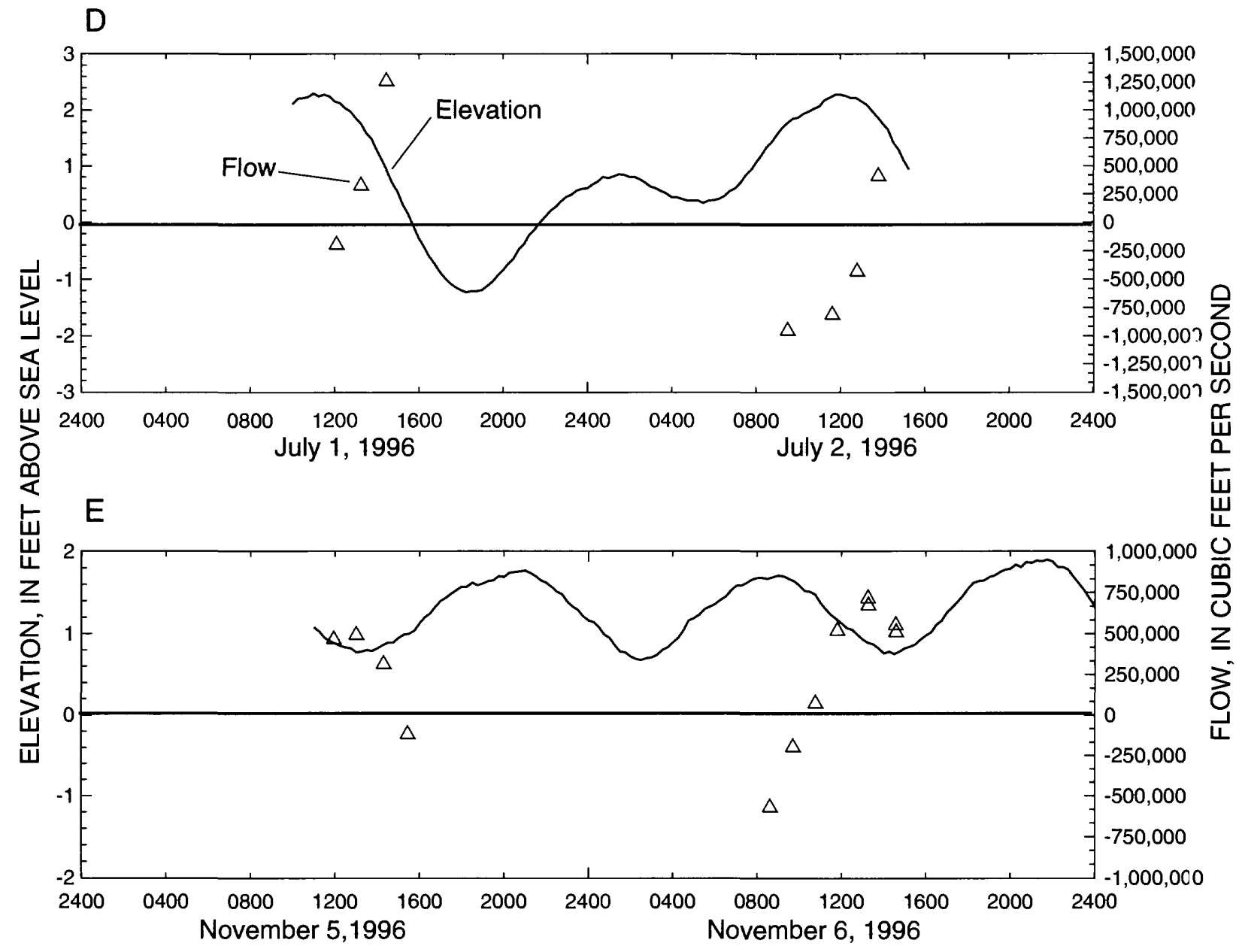

Figure 11. Flow and tidal elevation at the mouth of Tampa Bay, Florida - Continued.

flow vectors for the boat path are shown in figure 12 and the corresponding tidal elevation is shown in figure 11E. Figure 12A shows a fairly uniform flood tide. Figure $12 \mathrm{~B}$, when the flow velocity is beginning to slow, shows bidirectional flow patterns in the Egmont Channels and east of Passage Key. In figure $12 \mathrm{C}$, the northern part of the cross section exhibits flood-flow patterns, while the southern part exhibits ebb-flow patterns, with particularly strong flows in Passage Key Inlet. In figures $12 \mathrm{D}, 12 \mathrm{E}$, and $12 \mathrm{~F}$, the ebb flow becomes more organized, but the effects of Passage Key, the Egmont and Southwest Channels are still apparent. Note that the water is still flooding about 2 hours after the water level begins to decline (figs. 11E, 12A, and 12B).

Typical velocity distributions of ebb, flood, and near slack flows are presented in three measurement cross sections (fig. 13). The influence of Egmont Channel, Southwest Channel, and Passage Key Inlet can be seen in increased velocities for those sertions. Conversely, Egmont and Passage Keys inhibit flow and even cause flow reversals. Velocity patterns near slack flow indicate flood flow in Egmont Channel and ebb flow in Passage Key Inlet (fig. 13C).

Freshwater inflows typically do not affect flow patterns at the mouth of Tampa Bay; however, a large freshwater inflow event in August 1995 created vertically stratified flows. Stratified flow conditions result if freshwater inflow travels on top of the heavier, more saline water from the Gulf of Mexico. Vertically stratified flow in cross-section velocity plots can be seen only during flood flows. During ebb flows, vertical velocity profiles are uniform and freshwater inflows 

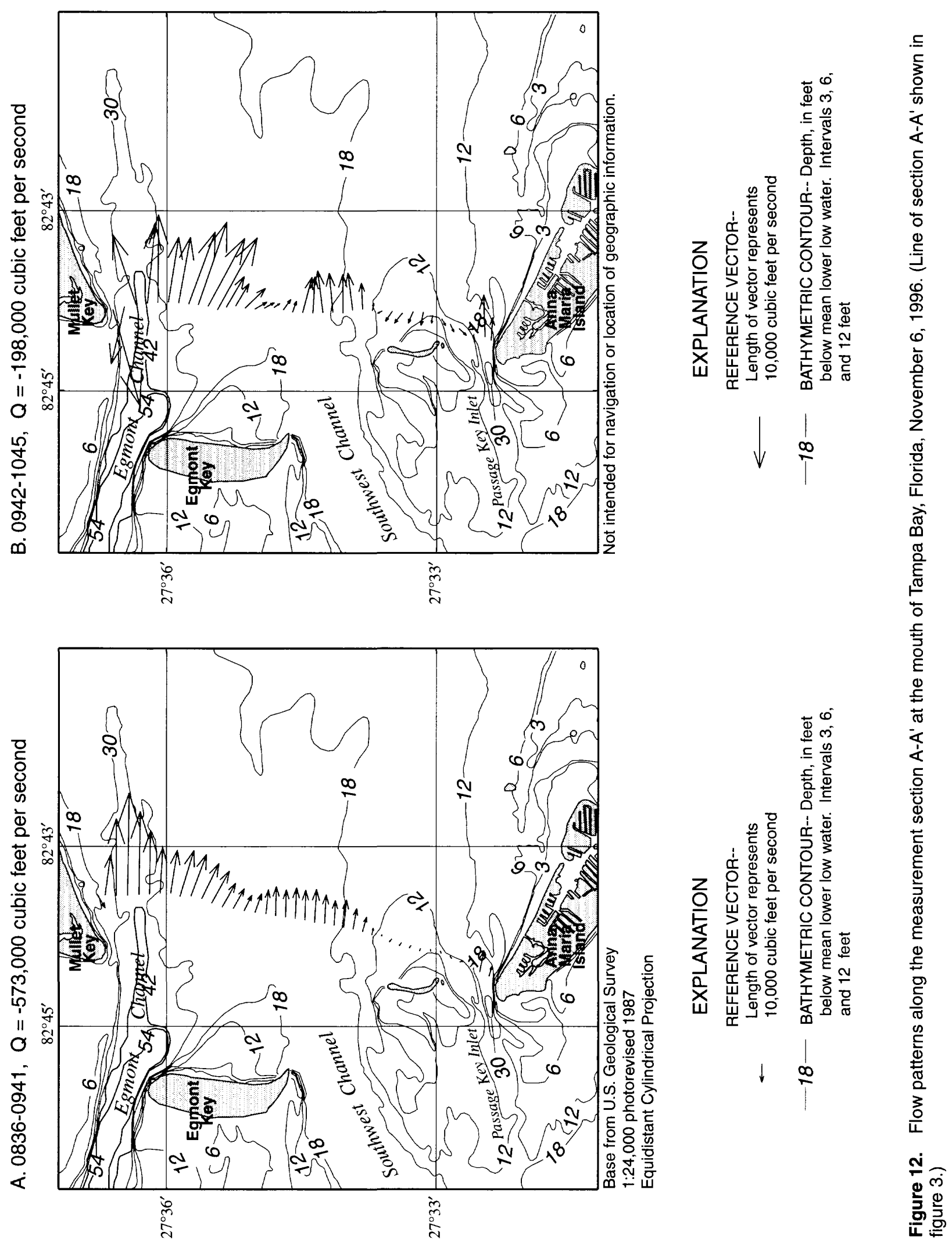

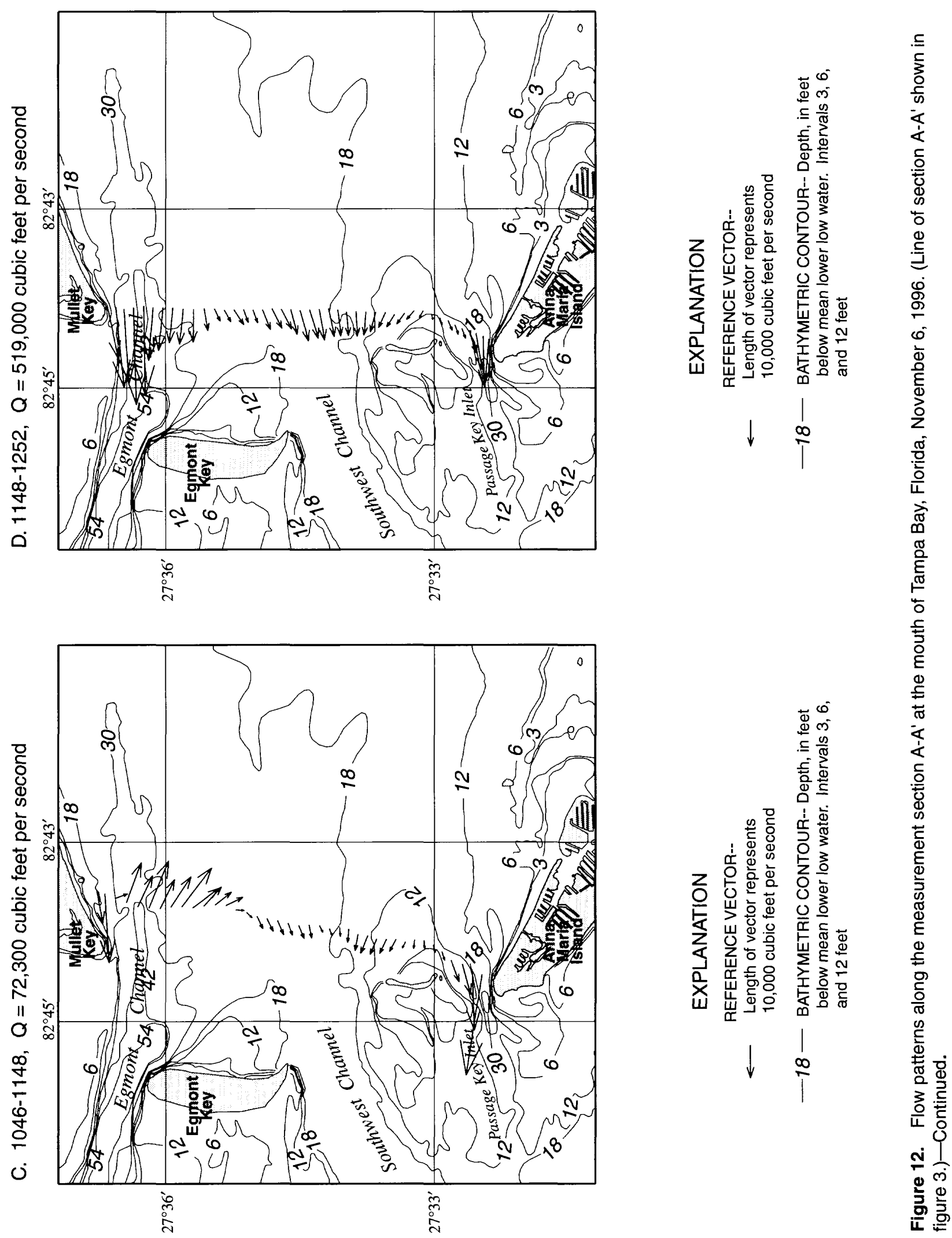

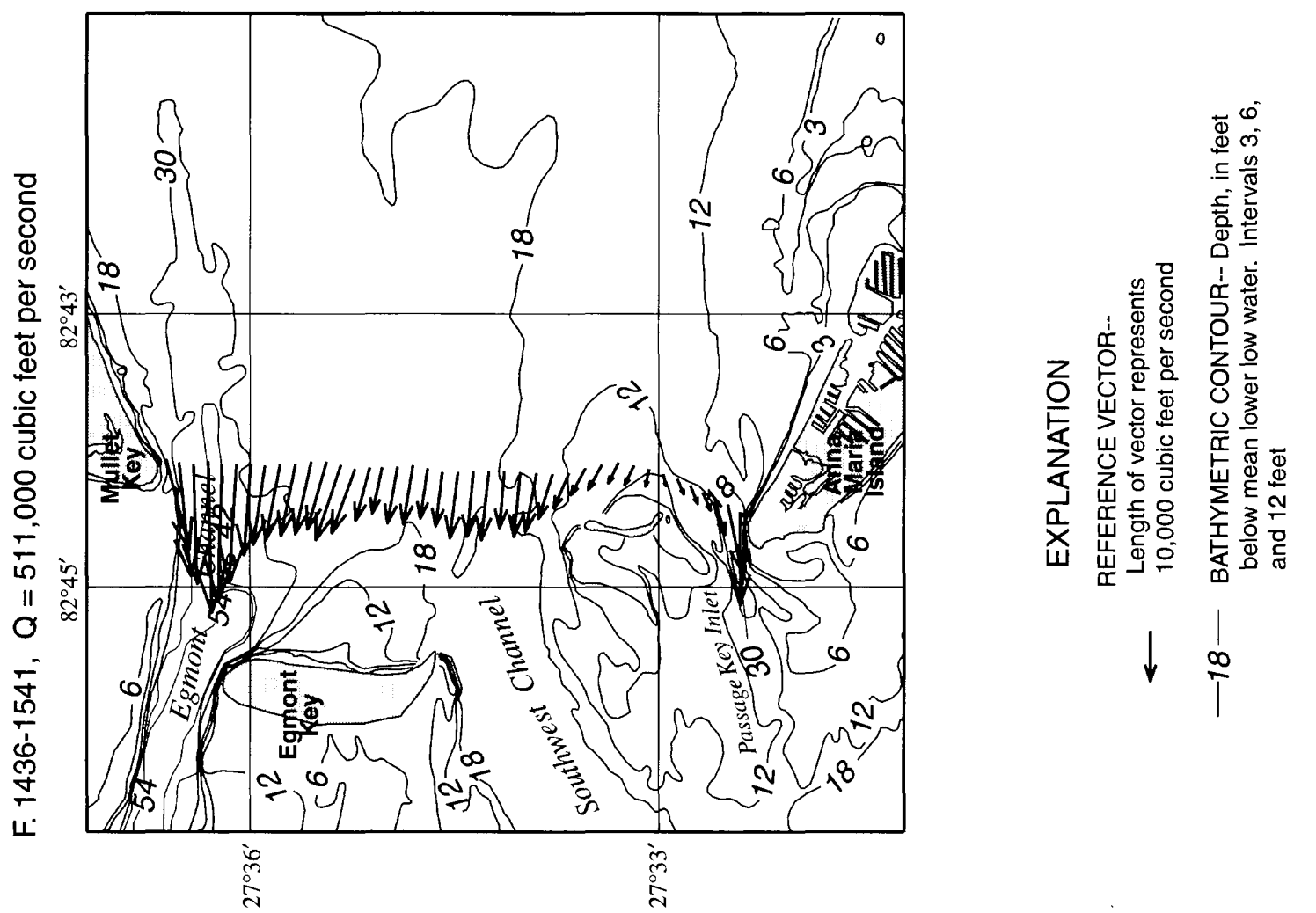

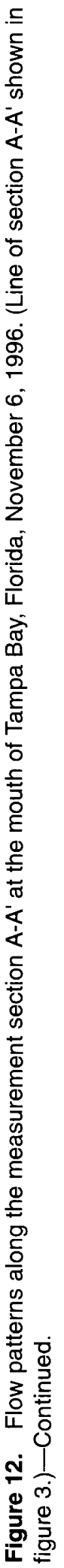
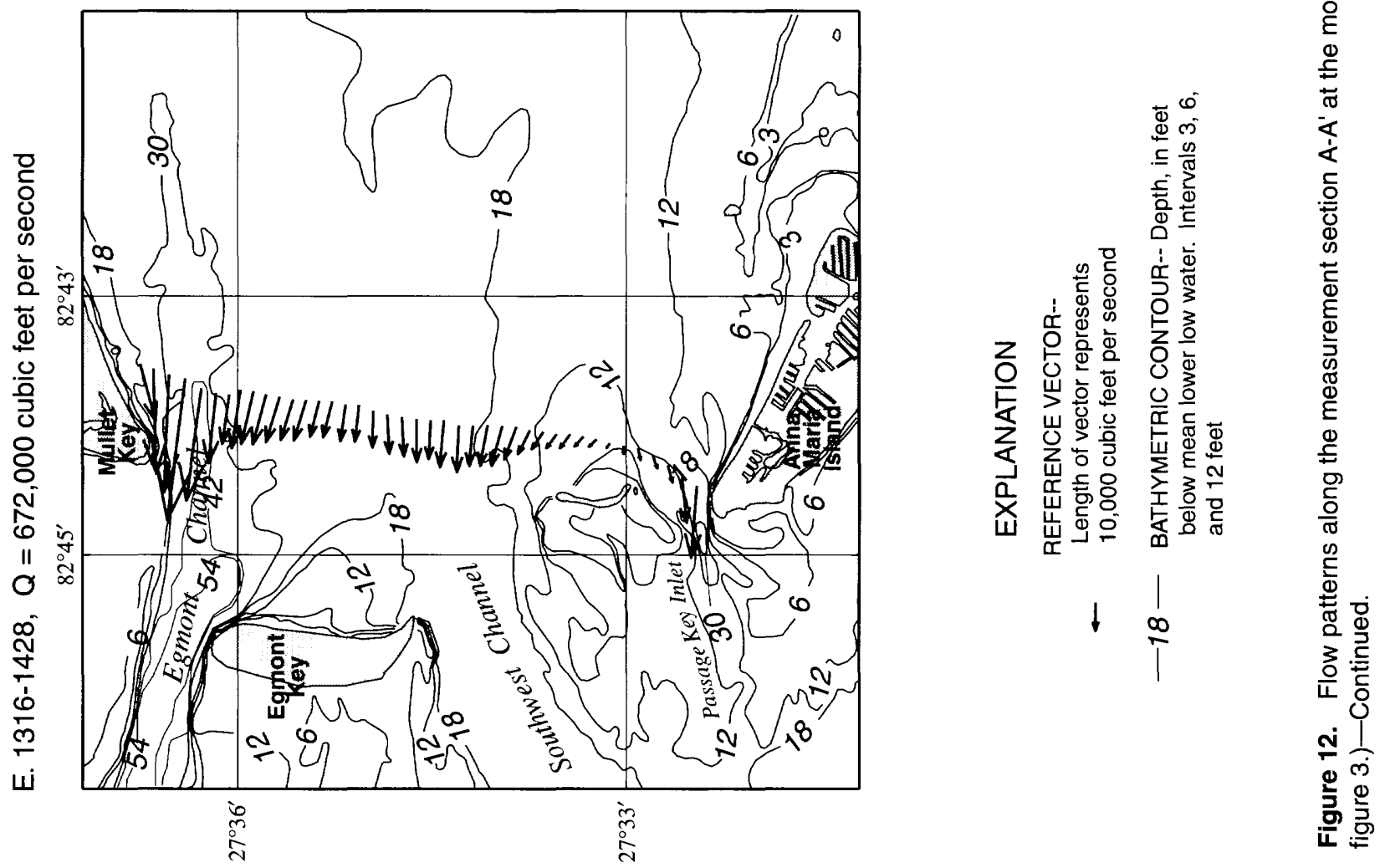

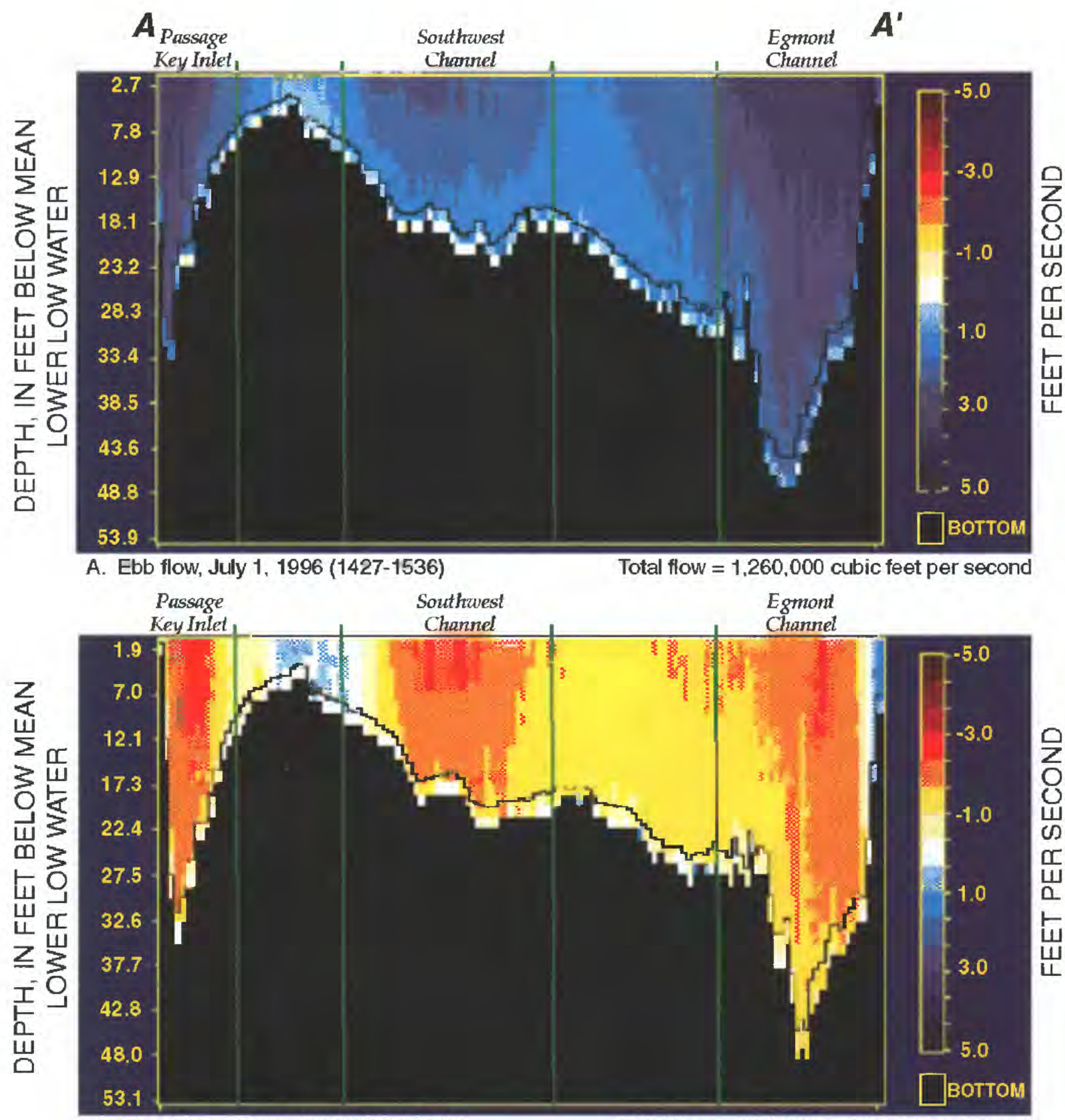

B. Flood flow, July 2, $1996(0929-1040) \quad$ Total flow $=-954.000$ cubic feet per second

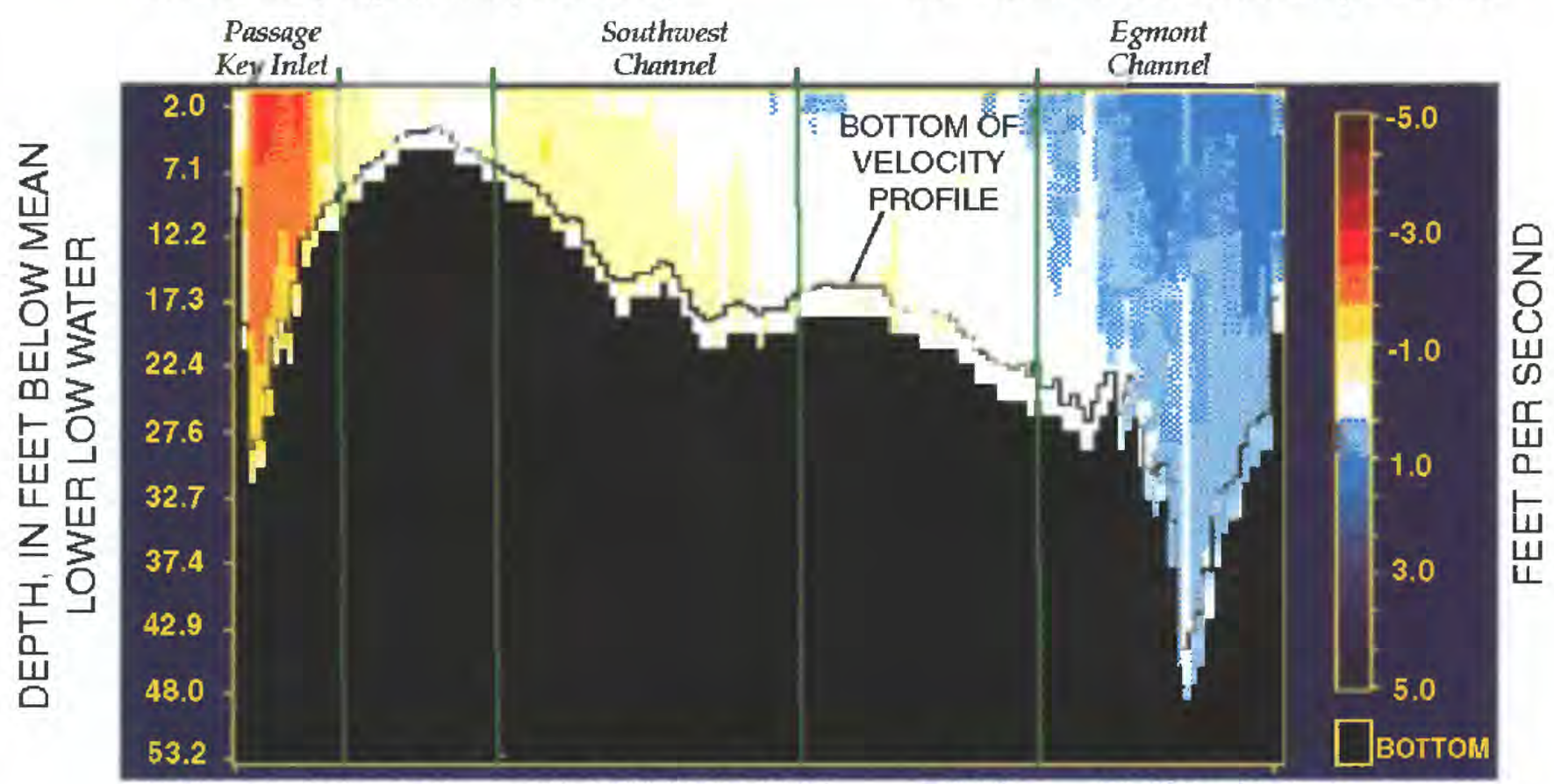

C. Near slack flow, Febnuary 21, $1996(0908-1023) \quad$ Total flow $=-16,300$ cubic feet per second

Figure 13. Velocities at the mouth of Tampa Bay, Florida, for (A) ebb, (B) flood, and (C) near slack flows. (Line of section A-A' shown in figure 3.) 
would be indistinguishable. On August 16, 1995, a large amount of freshwater inflow was moving toward the Gulf, while flood-flow conditions were moving water into Tampa Bay (fig. 14A). Within an hour (fig. 14B), flood flow was dominating the velocity patterns and little stratification was observed. Specific conductance of the water decreased from south to north along the boat path, and tannin-stained water was observed in Passage Key Inlet during this measurement. Tannin-stained water is a tea-brown color and is typical of many freshwater rivers and streams in Florida.
Percentages of flow in each channel were analyzed using typical flood-and ebb-flow measurements. Generally, the Egmont Channel carried 37 to 44 percent of total flow, the Southwest Channel carried 23 to 30 percent of total flow, and Passage Key Inlet carried 4 to 10 percent of total flow at the mouth of Tampa Bay. Goodwin (1987) used a numerical model to estimate the flow at the mouth of Tampa Bay. These data were for individual sites (model grids) within the channels and are useful for comparison to the percentages of total flow. A site in Egmont Channel carried 49 to 62 percent of total flow, a site in the Southwest
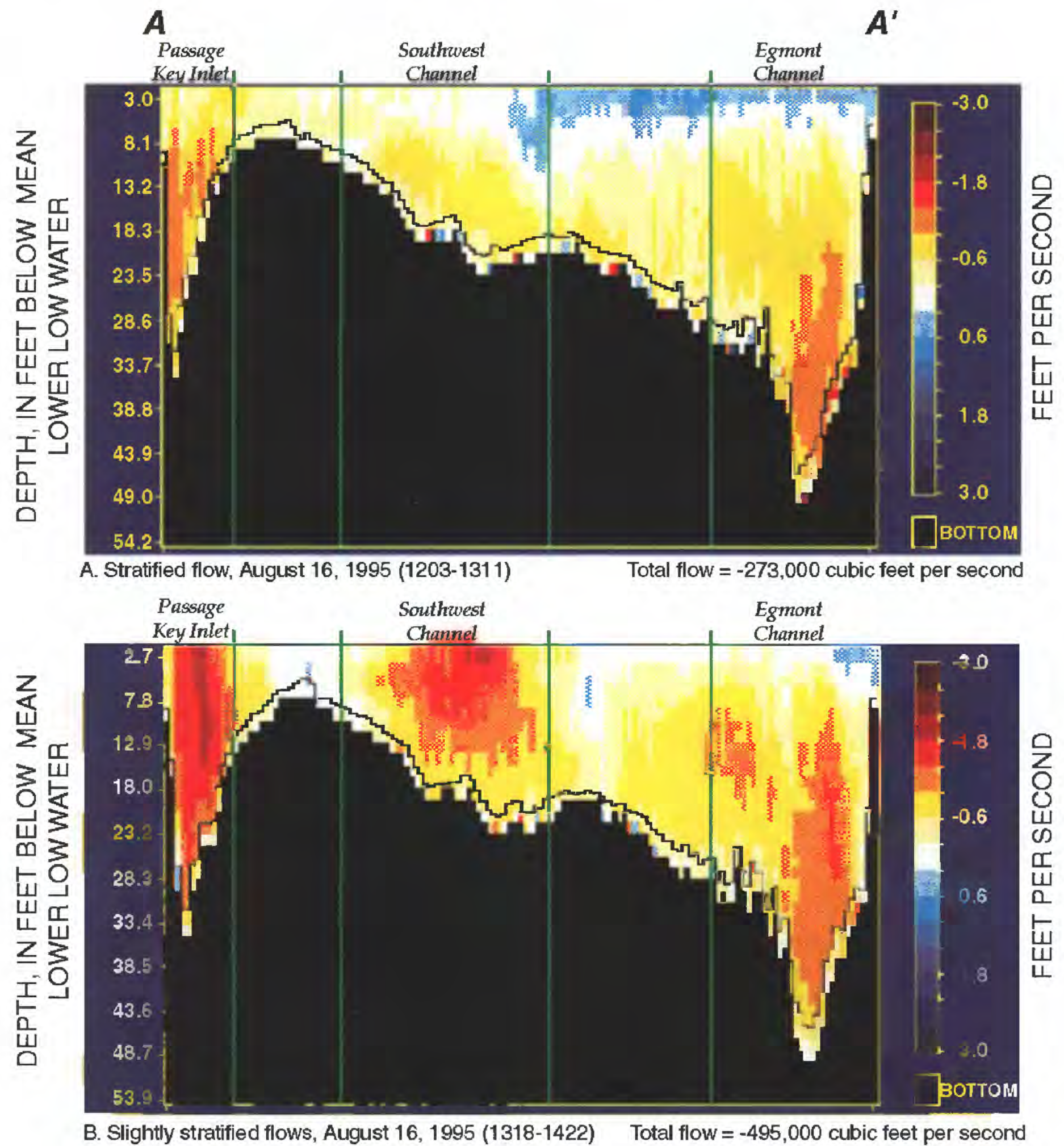

Figure 14. Velocities at the mouth of Tampa Bay. Florida, for (A) stratified flows, and (B) slightly stratified flows. (Line of section A-A' shown in figure 3 .) 
Channel carried 31 to 34 percent of total flow, and a site in Passage Key Inlet carried 7 to 17 percent of total flow at the mouth of Tampa Bay (Goodwin, 1987). Goodwin (1987) noted that "regions of high transport are generally coincidental with deep, fastflowing areas of the bay and that low transport regions are coincidental with shallow areas."

Flow data collected by NOAA in 1990 and 1991 were of the same order of magnitude and range as those collected in this study (Zervas, 1993). However, NOAA used a narrow-band ADCP that was not capable of measuring in shallow water (less than $15 \mathrm{ft}$ ). NOAA measurements of flow in August 1991 indicated a maximum ebb flow of about $1,270,000 \mathrm{ft}^{3} / \mathrm{s}$ and a flood flow of about $-1,095,000 \mathrm{ft}^{3} / \mathrm{s}$. Measurements made near slack flow were about $35,000 \mathrm{ft}^{3} / \mathrm{s}$ and $-177,000 \mathrm{ft}^{3} / \mathrm{s}$. These measurements, and other data, were used to calibrate a numerical model, which showed that the majority of flow at the mouth of Tampa Bay was in the Egmont Channel. The scale of the model did not allow for detailed analysis of channel flows.

\section{Anna Maria Sound}

Twenty-five flow measurements made in Anna Maria Sound ranged from an ebb flow of $16,700 \mathrm{ft}^{3} / \mathrm{s}$ to a flood flow of $-13,300 \mathrm{ft}^{3} / \mathrm{s}$. Measurements made near slack flow were 239 and $-183 \mathrm{ft}^{3} / \mathrm{s}$. Flows measured at Anna Maria Sound are plotted with tidal elevation (fig. 15). Additional measurements were made at this site, but because of the difficult measuring conditions (shallow depths and slow velocities), these measurements had to be discarded. Slack flow lagged minimum tidal elevation by about 3 hours for flows measured in December 1995 (fig. 15C). Wind speeds of about 8 to $10 \mathrm{mi} / \mathrm{h}$ from the northeast were recorded during the flow measurements and probably affected the flows. Slack flow was almost simultaneous with maximum tidal elevations during the November 1996 measurements (fig. 15D).

Simultaneous measurements of flow were made at the mouth of Tampa Bay and in Anna Maria Sound in November 1996. Flow measured at the mouth of Tampa Bay progressed from a flood flow of about $573,000 \mathrm{ft}^{3} / \mathrm{s}$ to a maximum ebb flow of $716,000 \mathrm{ft}^{3} / \mathrm{s}$ (fig. 11). Both sites approached slack flow within an hour of one another, indicating that they were generally in phase during this measurement period. The wind was between 3 and $4 \mathrm{mi} / \mathrm{h}$ from the west during these measurements and did not have a significant effect on flows at the mouth of Anna Maria Sound.
Total daily freshwater inflow from the Manatee and the Braden Rivers averaged about $4.5 \mathrm{ft}^{3} / \mathrm{s}$ for the first week in November, and was insignificant relat ve to the flows in Anna Maria Sound. Averaged flow vectors along the boat path (B-B') for the simultaneous measurements during flood (figs. 16A, B, C) and ebb (figs. 16D, E, F) flows at the mouth of Tampa Bay present the flow patterns at Anna Maria Sound. Bathymetry data available for this section did not match the measured depths and so are not inclided on the illustration. Although there was a strong flond flow at the mouth of Tampa Bay, the first measurement at the sound (fig. 16A) had an unorganized flow pattern, which could be the result of the small (less than 1 hour) phase lag. Flow patterns for the next two measurements (figs. 16B, 16C) are in the flood direction, but are less than 1 percent of the total flow at the mouth of Tampa Bay. These data indicate that flows at Anna Maria Sound were affected more by the small change in tidal elevation during the measurements than by the amount of flow coming through the mouth of Tampa Bay. Ebb flows (figs. 16D, E, F) are in the same direction as at the mouth of Tampa Bay, but are less than 1 percent of the total flow. These measurements were made during small changes in tidal elevation, and so the flows are small compared to the maximum flows measured at this site. More simultaneous data are needed to further understand the flow between these two systems.

Typically, the Intracoastal Waterway (fig. 3) carries about 77 to 80 percent of the total flow in and out of Anna Maria Sound. This conclusion is supported by studies that show that the majority of flow in shallow estuaries occurs in the relatively deep navigational channels (Goodwin, 1987; Sheng and others, 1994; Zervas, 1993; Levesque and Hammett, 1997).

The USGS began a cooperative study w'th the University of Florida in 1990 to examine flows in Sarasota Bay, and in particular, flows through Anna Maria Sound. As part of the study, the USGS measured flow in Anna Maria Sound north of the S tate Road 64 bridge in May 1992 (Sheng and others, 1994). Thirteen measurements of flow ranging from 1,900 to $11,000 \mathrm{ft}^{3} / \mathrm{s}$ were made using a broad-band ADCP. These flow data were used to calibrate a numerical model that was scaled to examine the flows in Anna Maria Sound (Sheng and Peene, 1993; Sheng and others, 1994). Flow patterns produced by this model indicated very low flows near the State Poad 64 bridge except in the Intracoastal Waterway which carried the majority of the flow at section B-B' (fig. 3). 


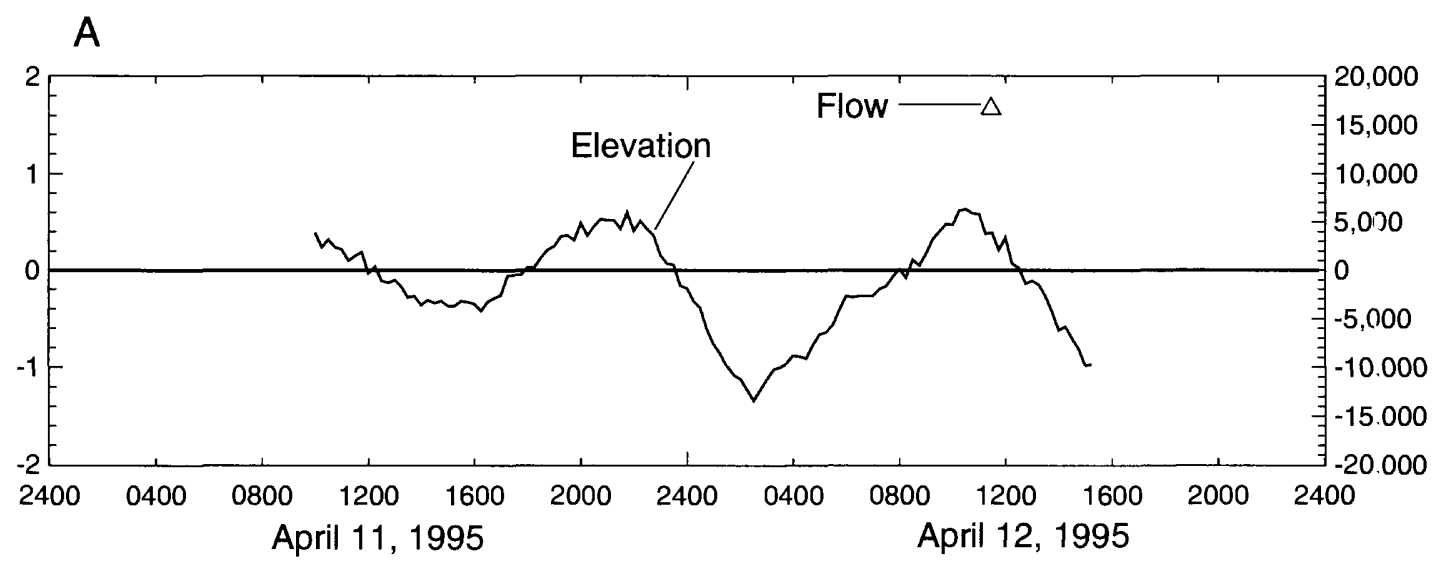

B

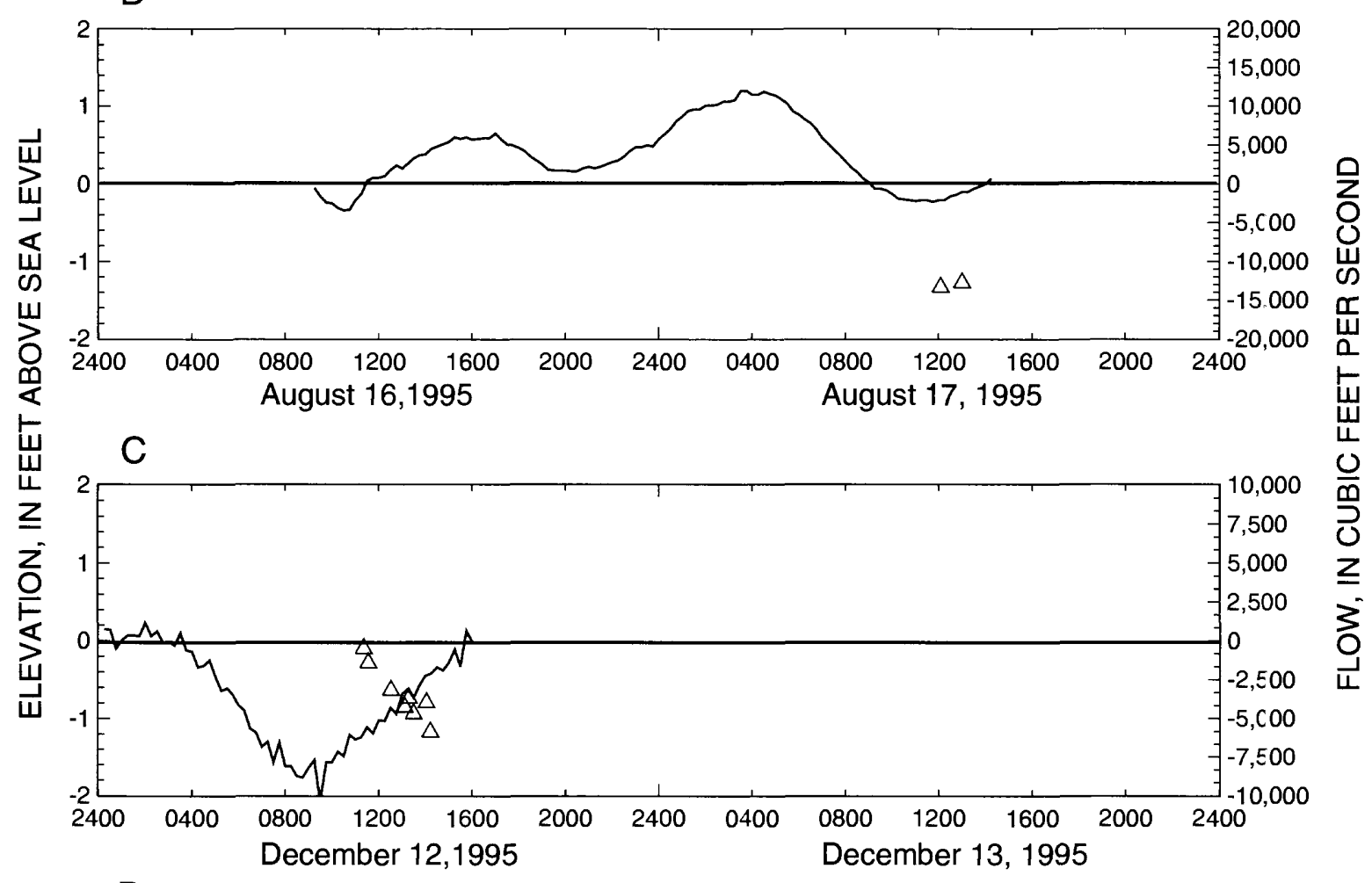

D

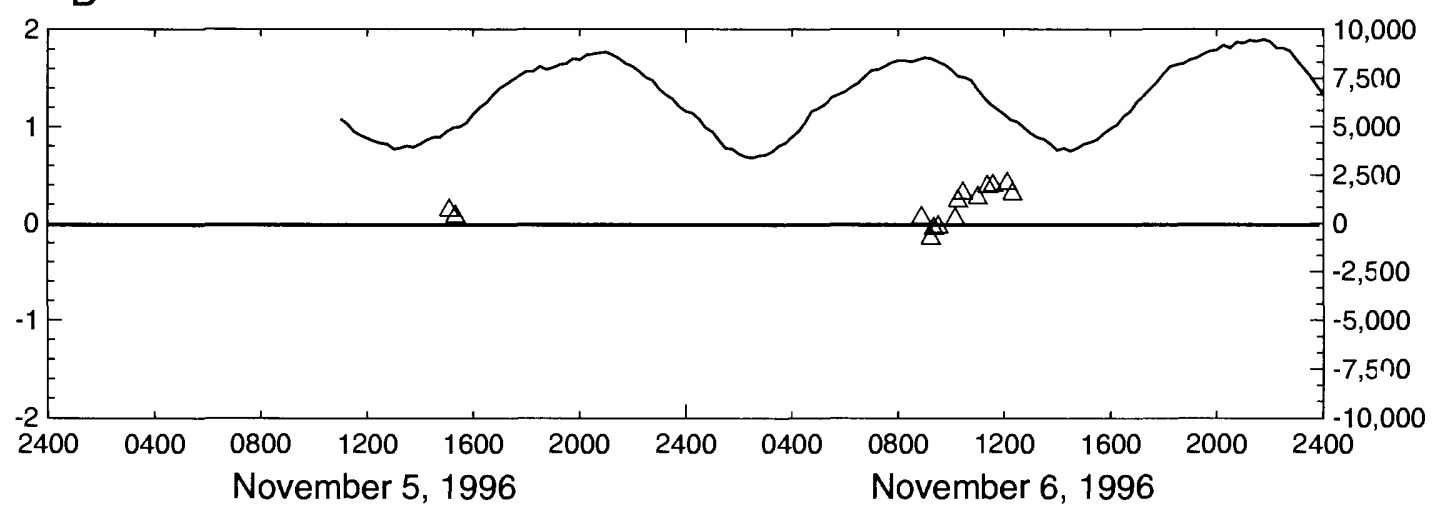

Figure 15. Flow and tidal elevation in Anna Maria Sound, Florida. 
A. $0858-0913, Q=300$ cubic feet per second

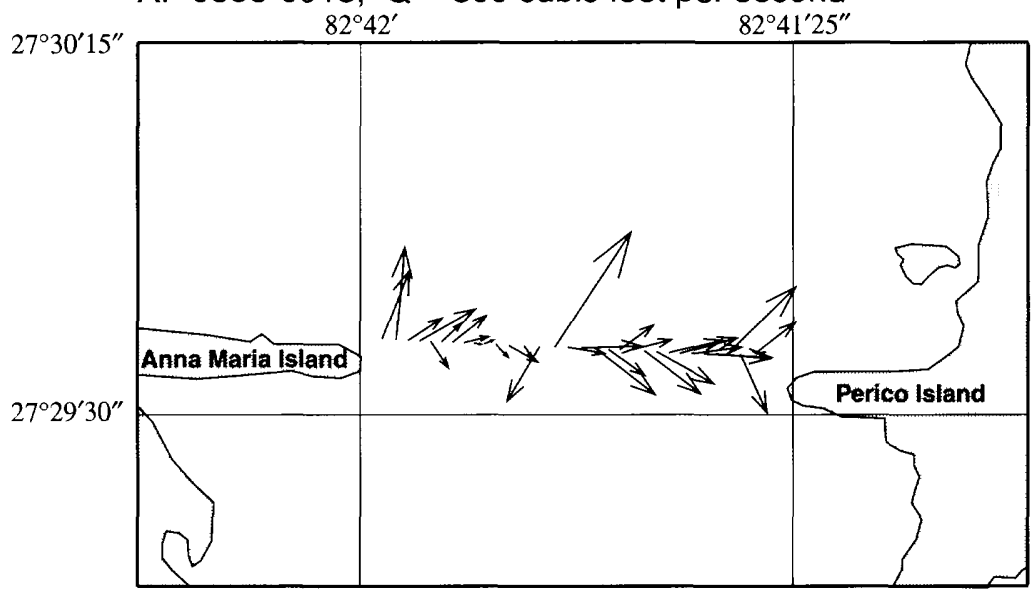

B. 0913-0928, $Q=-733$ cubic feet per second

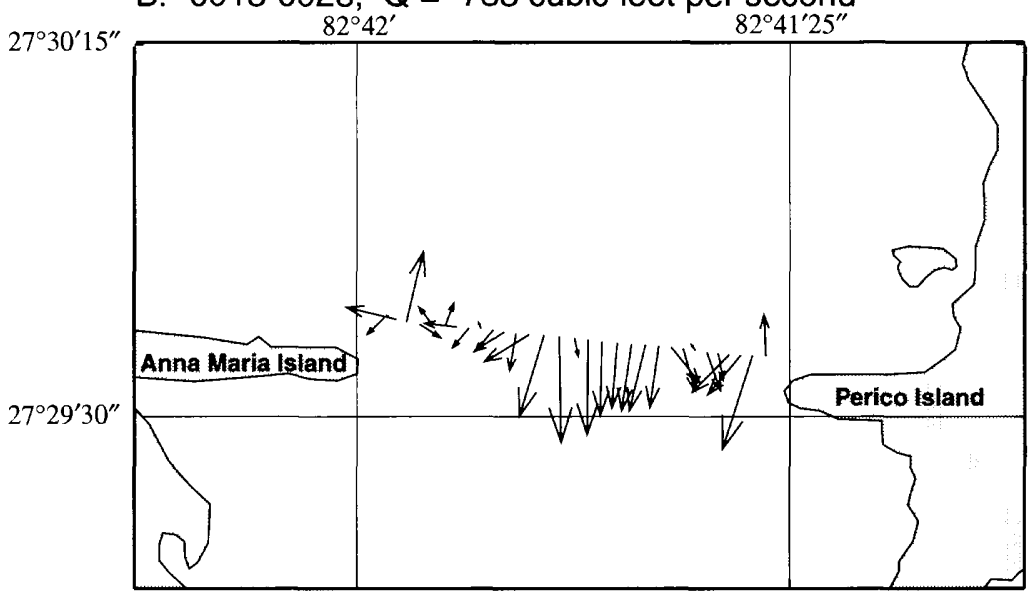

C. $0928-0943, Q=-276$ cubic feet per second

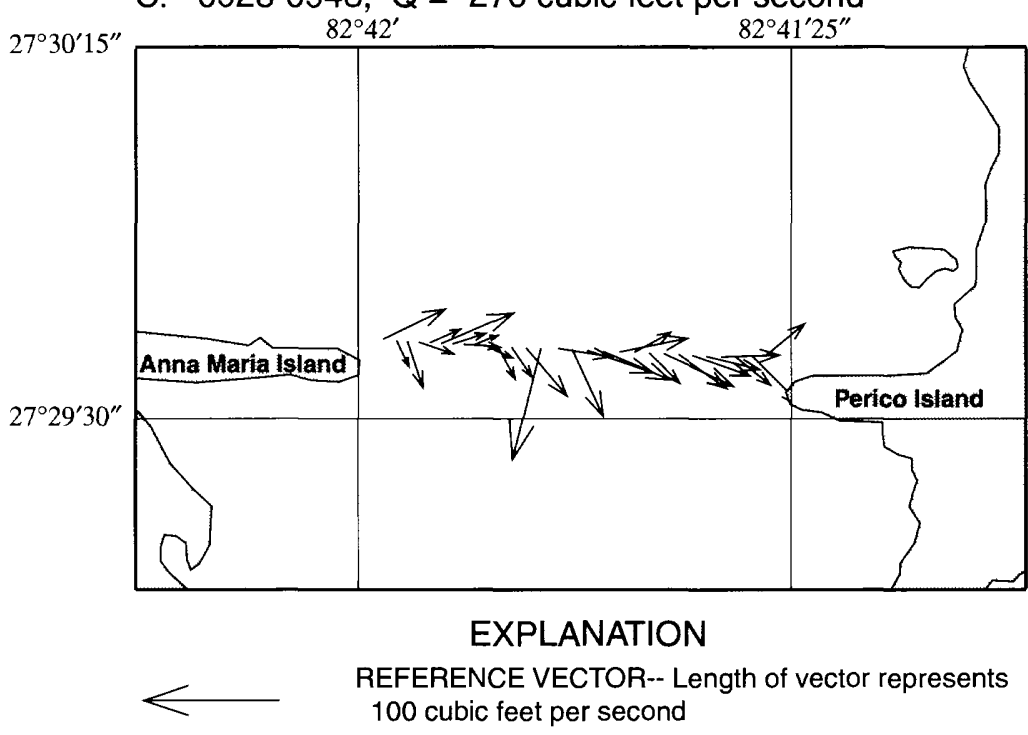

Figure 16. Flow patterns along the measurement section B-B' in Anna Maria Sound during simultaneous measurements at the mouth of Tampa Bay, Florida, November 6,1996 . (Flow at mouth $=-573,000$ cubic feet per second (08360941), shown in figures $11 \mathrm{E}$ and 12A.) (Line of section B-B' shown in figure 3.) 
D. $1150-1205, Q=1,970$ cubic feet per second

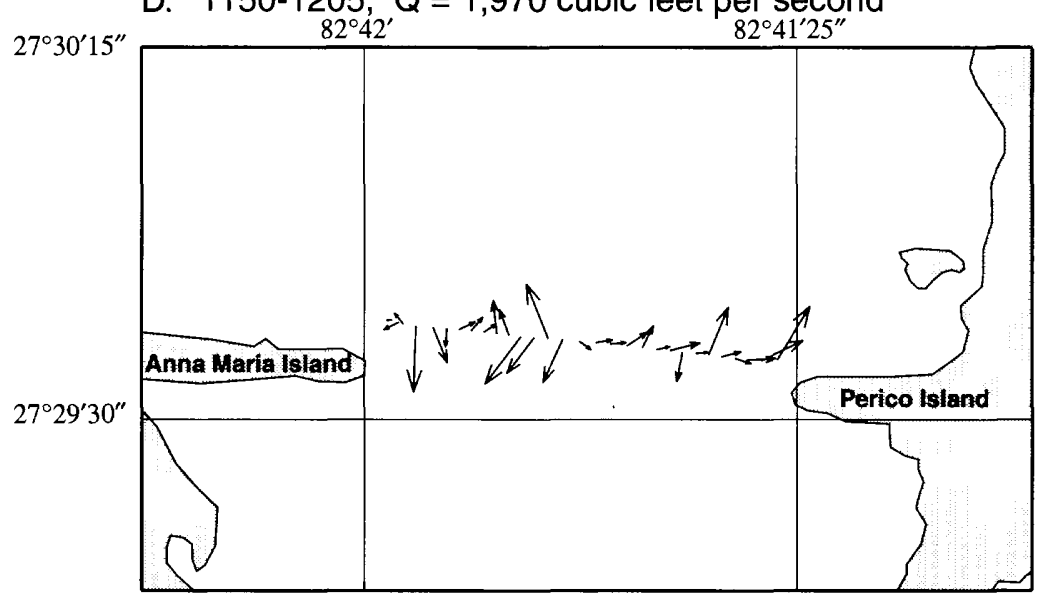

E. 1206-1220, Q = 2,070 cubic feet per second

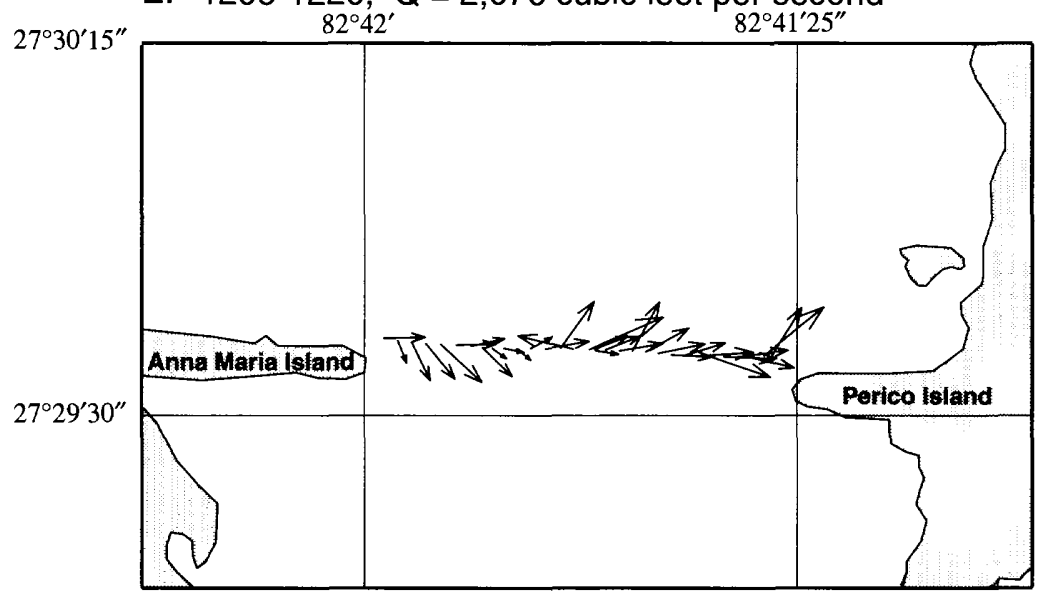

F. 1223-1238, $Q=1,530$ cubic feet per second

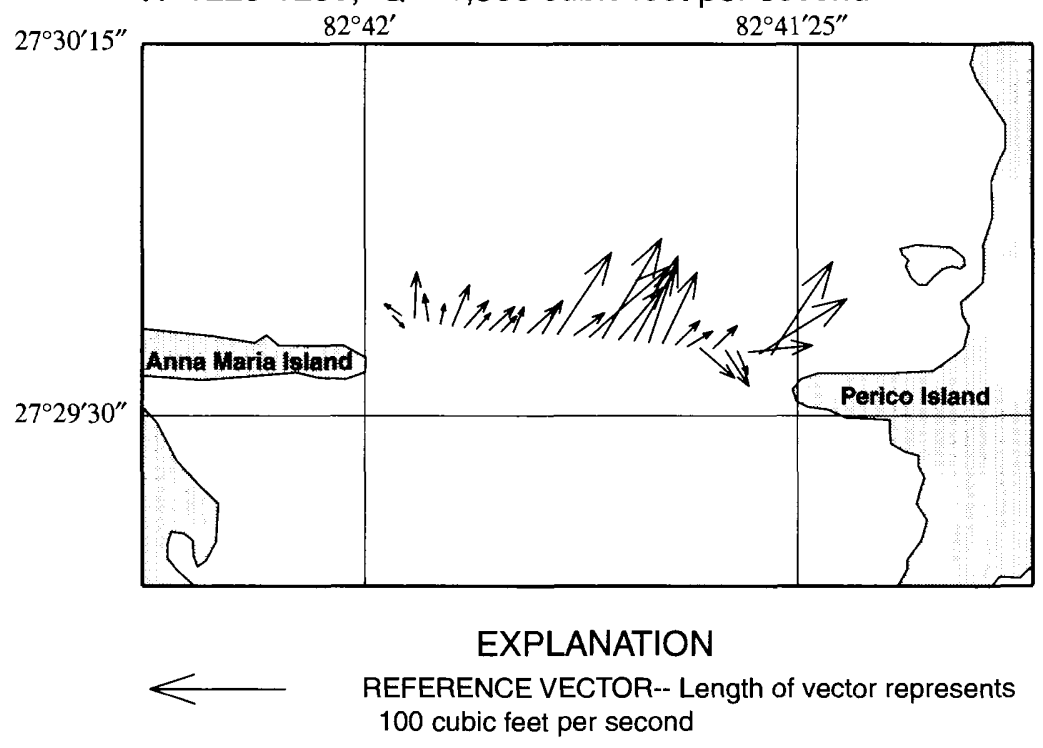

Figure 16. Flow patterns along the measurement section B-B' in Anna Maria Sound during simultaneous measurements at the mouth of Tampa Bay, Florida, November 6, 1996. (Flow at mouth $=-573,000$ cubic feet per second (0836-0941), shown in figures $11 \mathrm{E}$ and 12A.) (Line of section B-B' shown in figure 3.)-Continued. 


\section{Charlotte Harbor}

One hundred and twenty-six measurements of flow were made at the mouth of Charlotte Harbor (Boca Grande Pass) and ranged from 428,000 to $398,000 \mathrm{ft}^{3} / \mathrm{s}$. Measurements made near slack flow ranged from 18,200 to $-8,680 \mathrm{ft}^{3} / \mathrm{s}$. Flow and tidal elevation data (fig. 17) indicate that flow approaches zero (slack flow) about an hour after occurrence of a maximum or a minimum tidal elevation (fig. 17).

Flow patterns at Boca Grande Pass generally indicate unidirectional distribution except near slack flow. Averaged flow vectors demonstrate a wellorganized east, northeast flow pattern of a flood tide on July 9, 1996 (figs. 18A, B). Flood flows were affected by a circulation eddy created by a deep channel along the southeast end of Gasparilla Island. Flow patterns in figure $18 \mathrm{C}$ indicate flood flow in the deep channel but reversed flow (ebb) near the channel edges. The data in figure $18 \mathrm{D}$ indicate mostly ebb-flow patterns with some flood-flow vectors in the middle section. The data in figures $18 \mathrm{E}$ and $18 \mathrm{~F}$ indicate the welldeveloped, ebb-flow patterns typical of Boca Grande Pass. Flow patterns indicated that the greatest velocities are in the main channel for both ebb and flood flows.

Typical velocity distributions are shown for ebb, flood, and near slack flow in figure 19. A measurement made near slack flow demonstrates bidirectional flow with flood flow in the main channel and ebb flow near the channel edges (fig. 19C).

Flow typically was distributed evenly throughout Boca Grande Pass because of the uniform crosssectional depth, the lack of separate deep channels, and the narrow width of the pass (fig. 8). The cross section is deepest near the north end; as a result, the northern one-third of the cross-section width carries more than 50 percent of the total flow.

Twenty-two measurements of flow, ranging from 464,000 to $-300,000 \mathrm{ft}^{3} / \mathrm{s}$, were made by the USGS on July 17-18, 1986 (Goodwin, 1996). These flow measurements were made with point-velocity meters and moving-boat techniques using velocity measurements near the water surface for computation of flow. These data were used to calibrate a numerical model (Goodwin, 1996) and indicated the same evenly distributed flow patterns as were shown in the ADCP flow measurements.

\section{Pine Island Sound}

Measurements of flow within Pine Island Sound was difficult because of the shallow depths and a large surface area. Reconnaissance measurements were made on the north side of Pine Island Sound from Jug Creek Shoals to the northern tip of Cayo Costa Island (fig. 7). Data from these measurements delineate the general flow patterns in the area, but flow directly into and out of the sound could not be determined. To better define the flow into and out of the sound. measurements were made at sections D-D', E-E', and F-F' (fig. 7). During ebb flows at Boca Grande Pass, flows at section D-D' were northerly, at section E-E' westerly, and, surprisingly, at section F-F' southerly (fig. 20A). Flows at each section were reversed during flood flows at Boca Grande Pass (fig. 20B). Flow patterns shown in figure 20 are not significantly affected by wind or freshwater inflow.

Flow in Pine Island Sound is inhibited by the shallow depths and numerous shoals and islands. In this system, as in most estuarine systems in Florida, the flow moves primarily through the deep navigational or natural channels. The Intracoastal Waterway dominates the flow in section D-D' (fig. 7), typically carrying 38 to 64 percent of the total flow. The flow through section D-D' was generally in the same phase (flood or ebb) as Boca Grande Pass (section C-C') and carried about 3 to 4 percent of the total flow at the pass. The main channel at section D-D' generally carried a smaller percentage of the total flow during flood flows than ebb flows. Goodwin (1996) used Lagrangian particle-track simulations to determine flow patterns in this area, and reported a northerly residual flow at section D-D'. Section E-E' averaged about $6 \mathrm{ft}$ in depth and had a navigational channel about $10 \mathrm{ft}$ deep near the E' edge of the section (fig. 10). About 25 to 30 percent of total flow in section E-E' was in the navigational channel and about 20 percent was within $500 \mathrm{ft}$ of Useppa Island. Flow direction in section E-E' usually was to the east. when flows at section D-D' were southerly and to the west when flows at section D-D' were northerly. Flows at section E-E' were less than 1 percent of the total flow at Boca Grande Pass. Section F-F' bisects a natural channel that runs from Captiva Pass north toward Jug Creek Shoals (fig. 7). This natural channel, about $10 \mathrm{ft}$ deep, occupies about 45 to 50 percent of the crannel width and carries about 77 to 82 percent of the total 


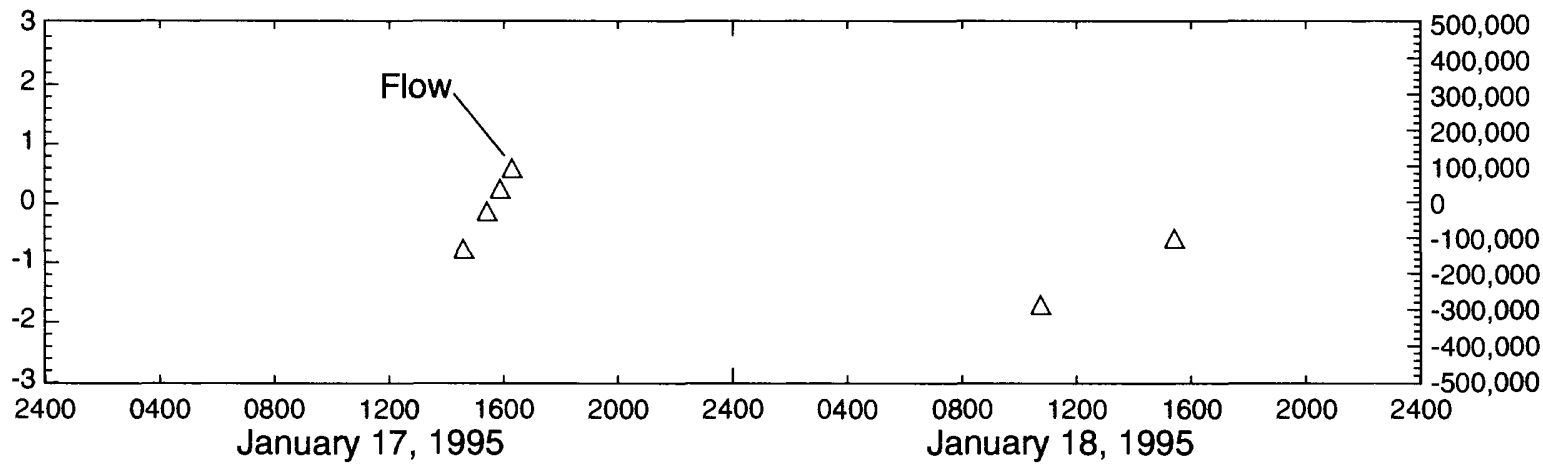

B

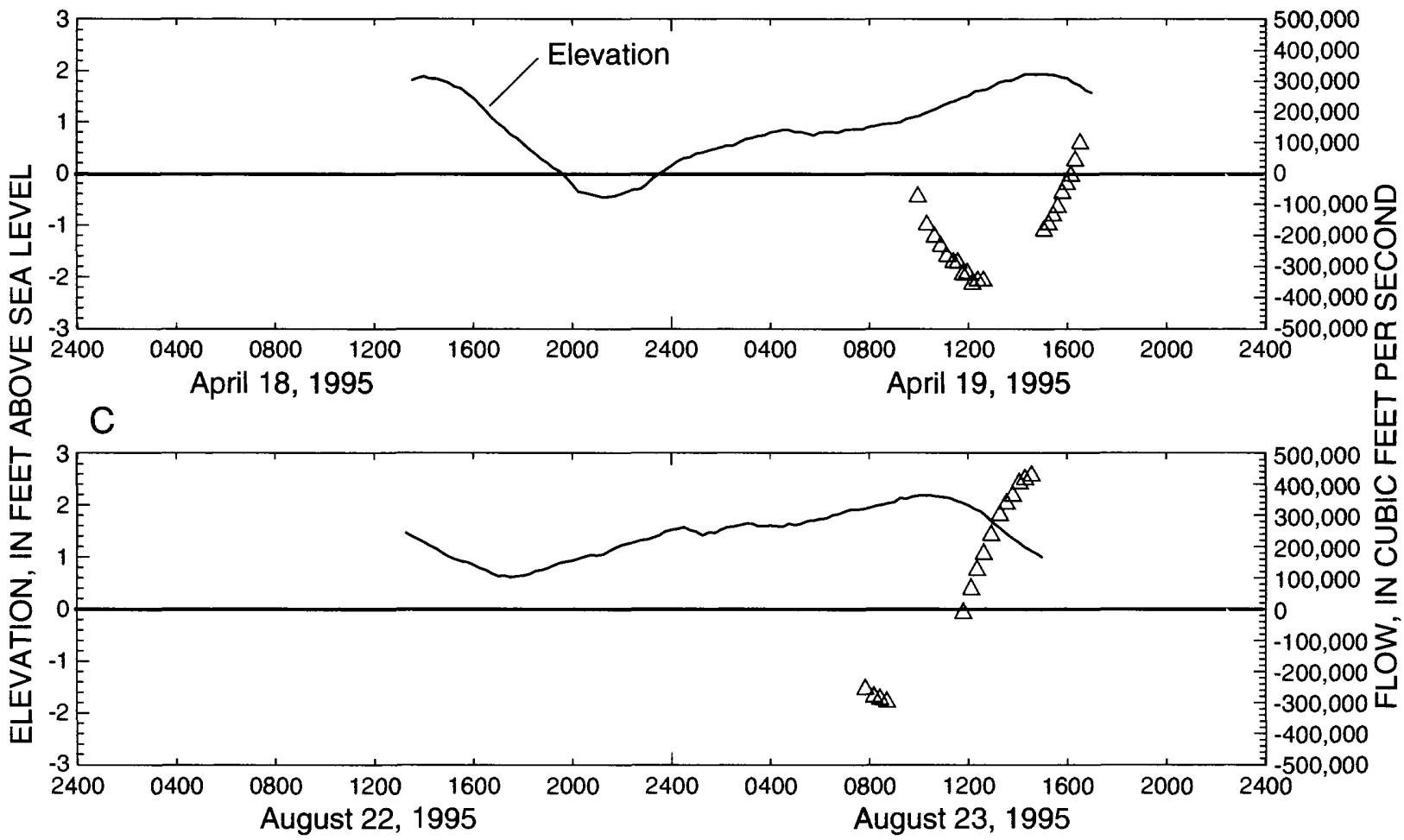

D

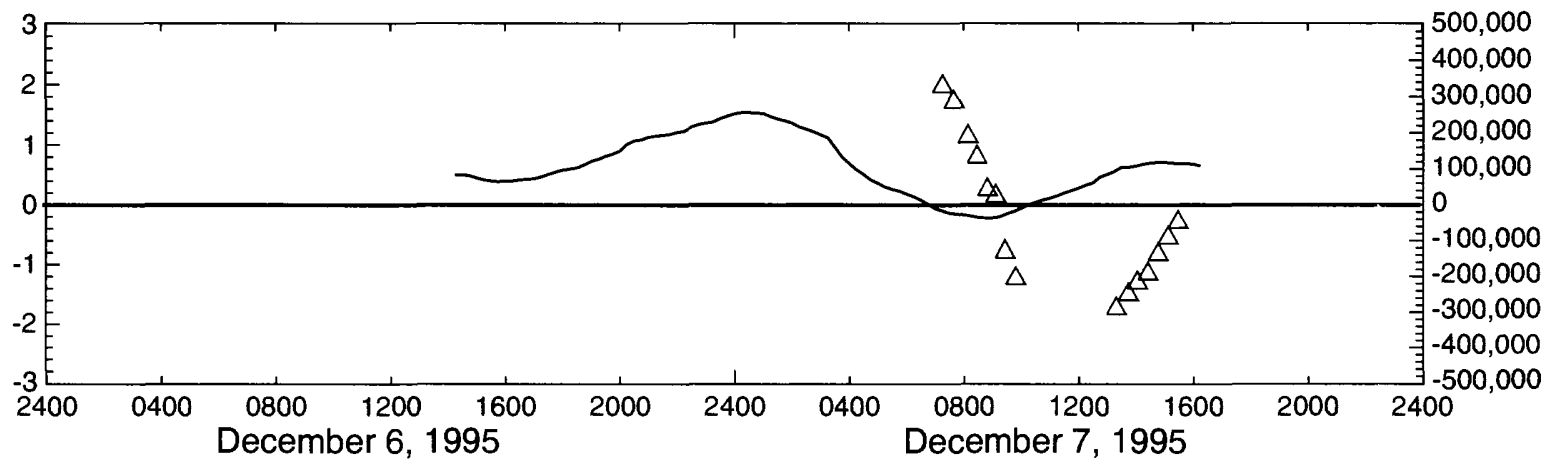

Figure 17. Flow and tidal elevation at the mouth of Charlotte Harbor, Florida. 

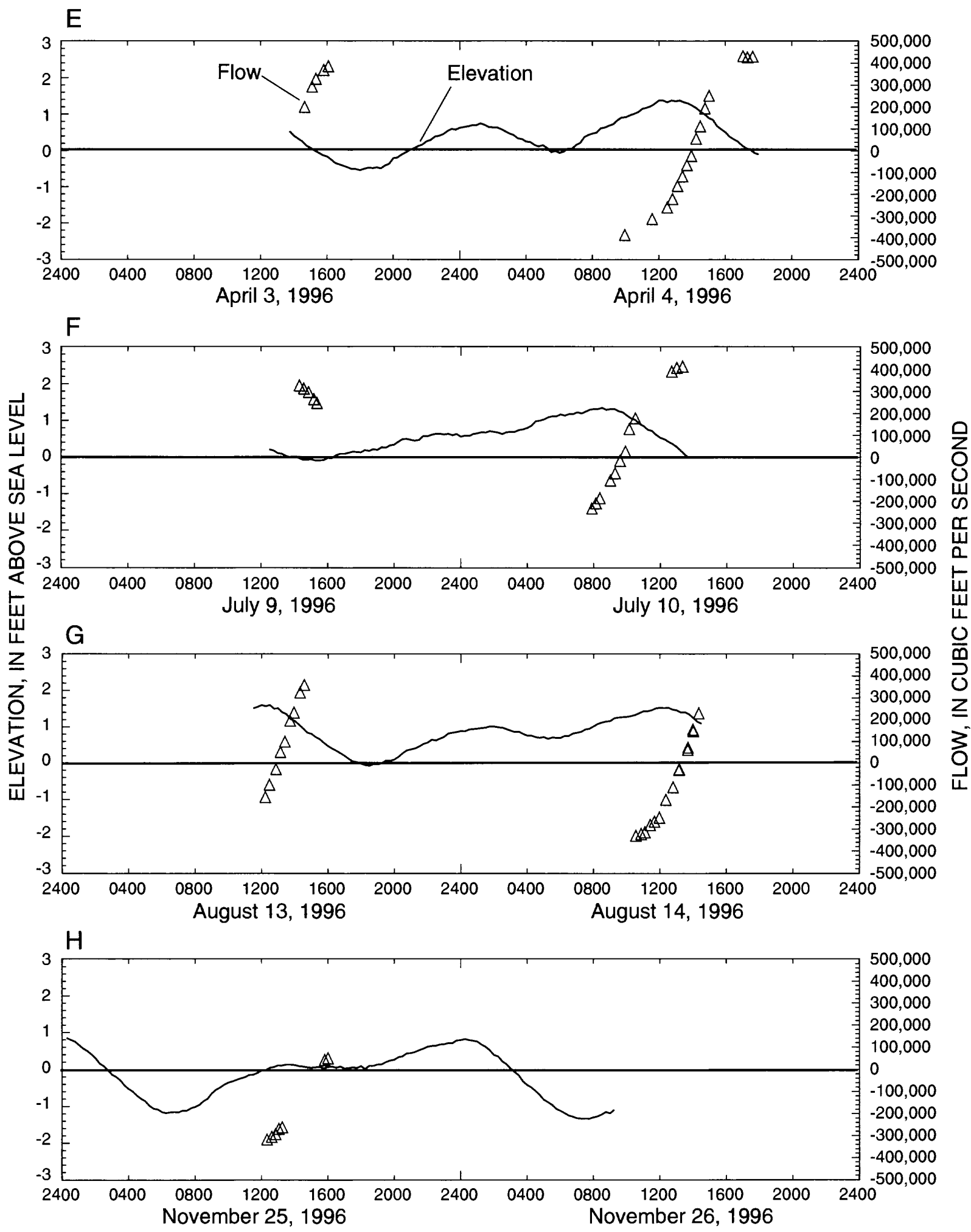

Figure 17. Flow and tidal elevation at the mouth of Charlotte Harbor, Florida-Continued. 

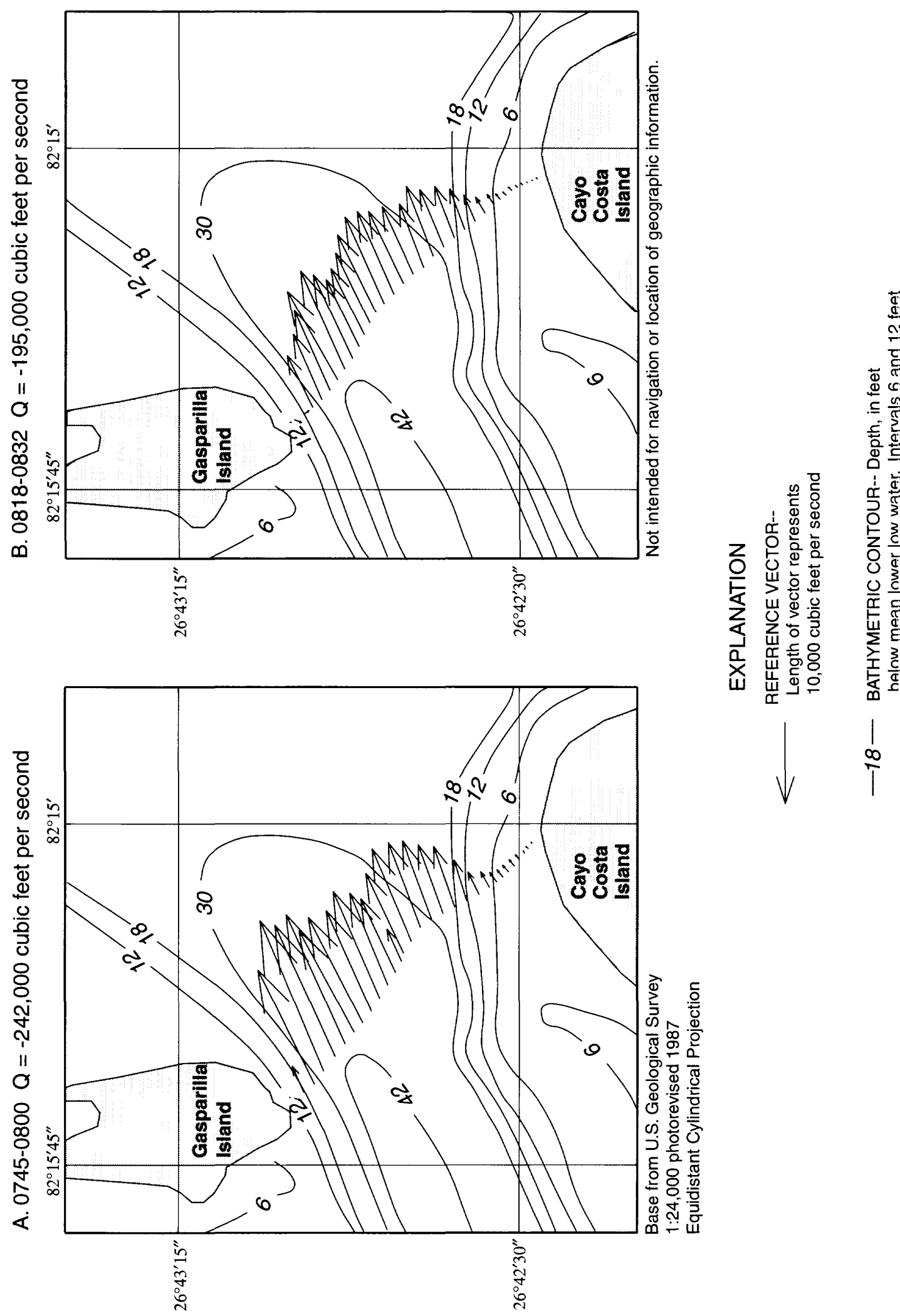

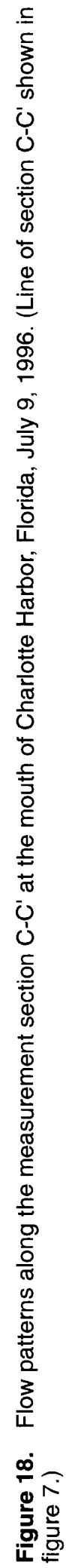



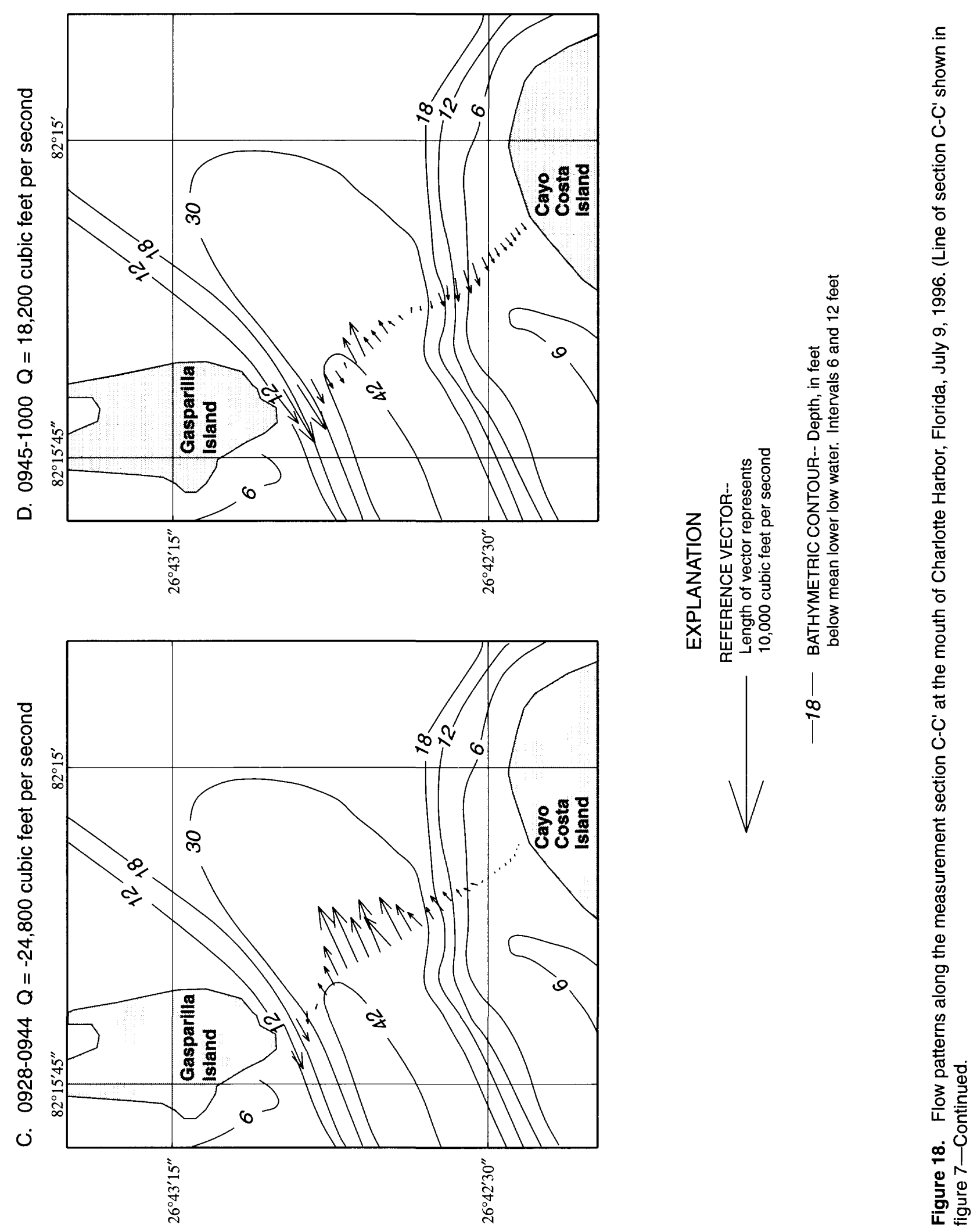

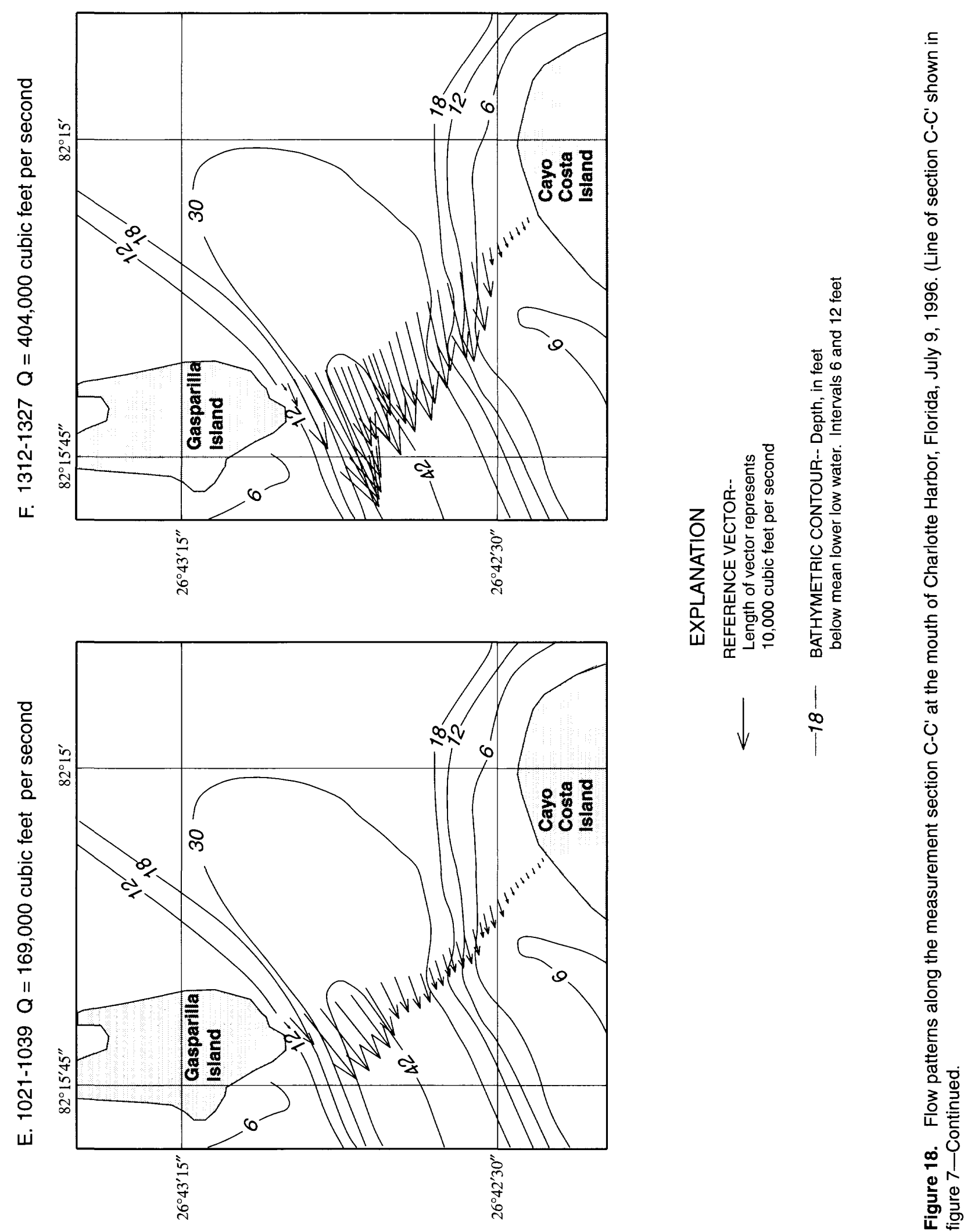


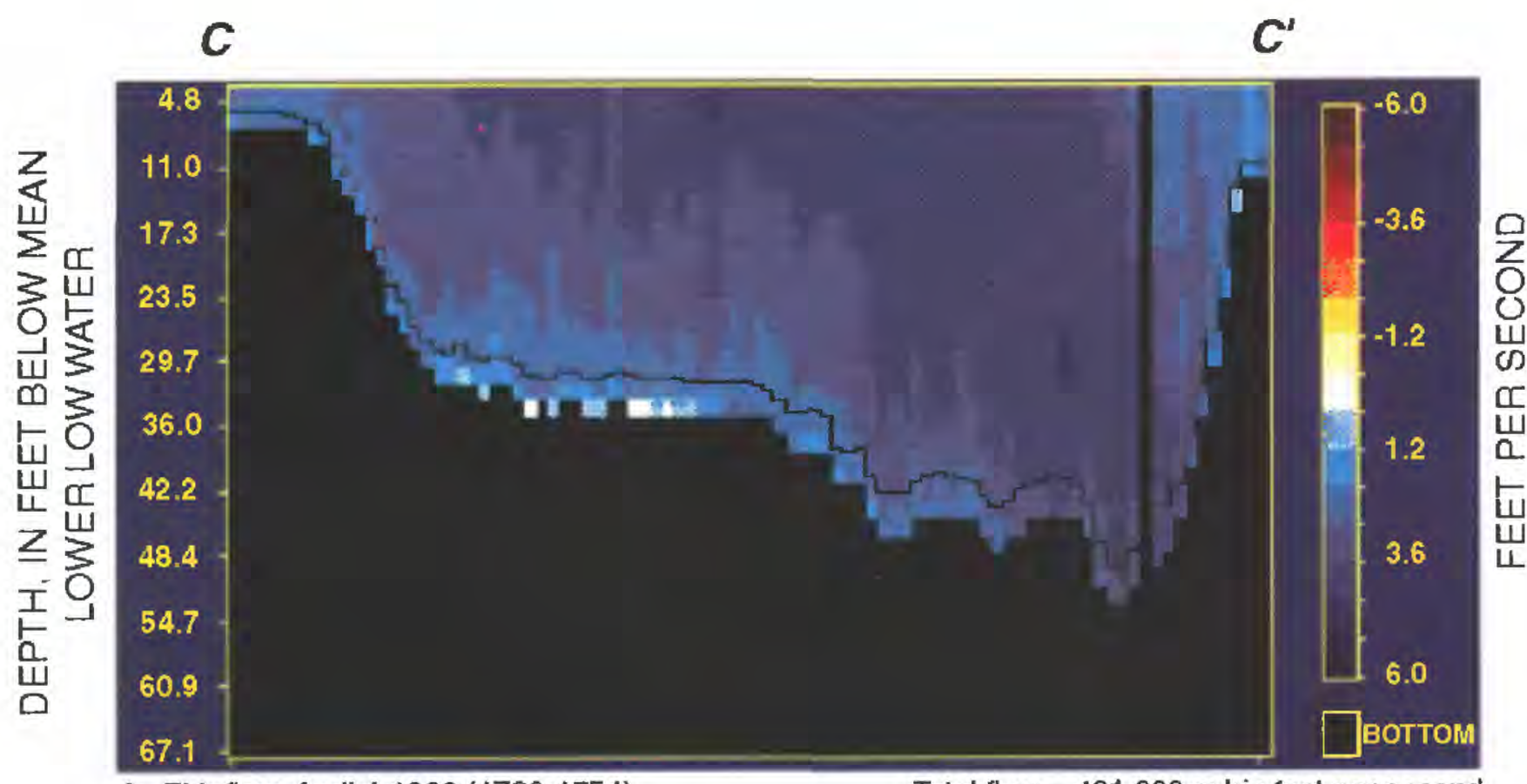

A. Ebb flow, April 4,1996 (1739-1754) Total flow $=421,000$ cubic feet per second
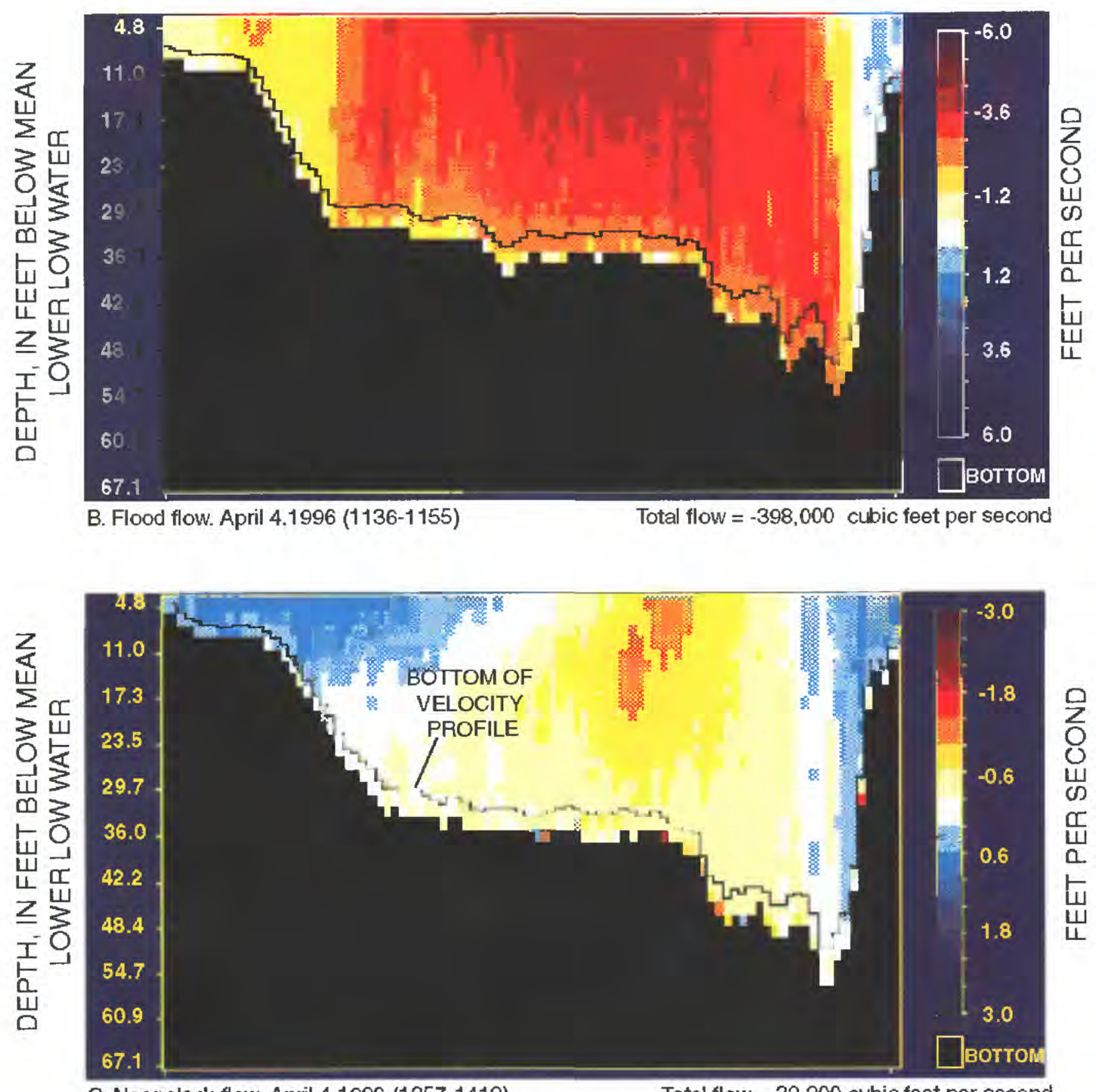

C. Near slack flow, April 4,1996 (1357-1412)

Total flow $=32,200$ cubic feet per second

Figure 19 Velocities at the mouth of Charlotte Harbor, Florida, for (A) ebb, (B) flood, and (C) near slack flows. (Line of section $\mathrm{C}-\mathrm{C}$ ' shown in figure 7.) 


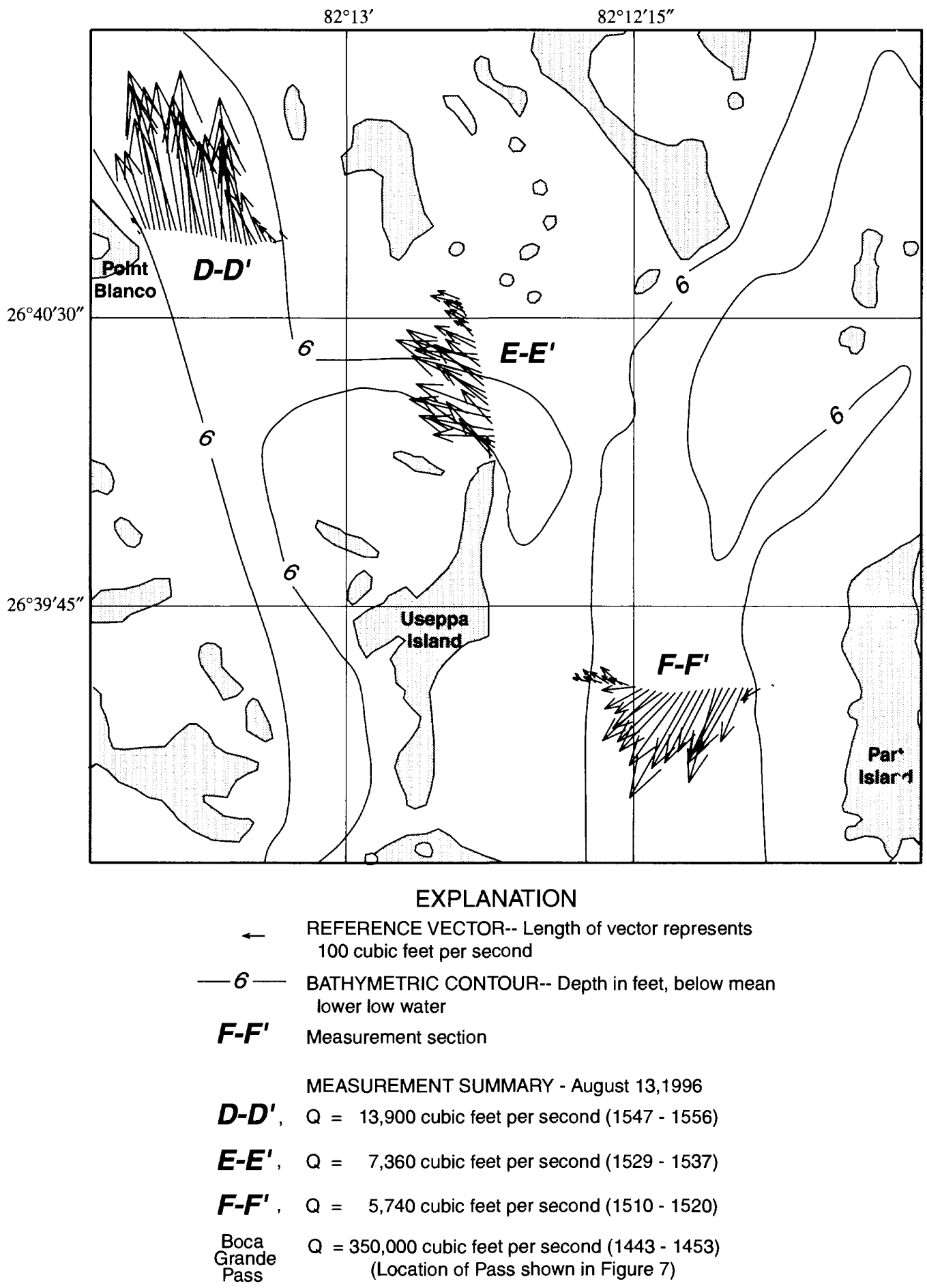

Figure 20. Flow patterns along measurement sections $D-D^{\prime}, E-E^{\prime}$, and $F-F^{\prime}$ in Pine Island Sound during simultaneous measurements at the mouth of Charlotte Harbor, Florida. (A) August 13, 1975 and (B) August 14, 1996. (Line of sections D-D', E-E', and F-F' shown in figure 7.) 


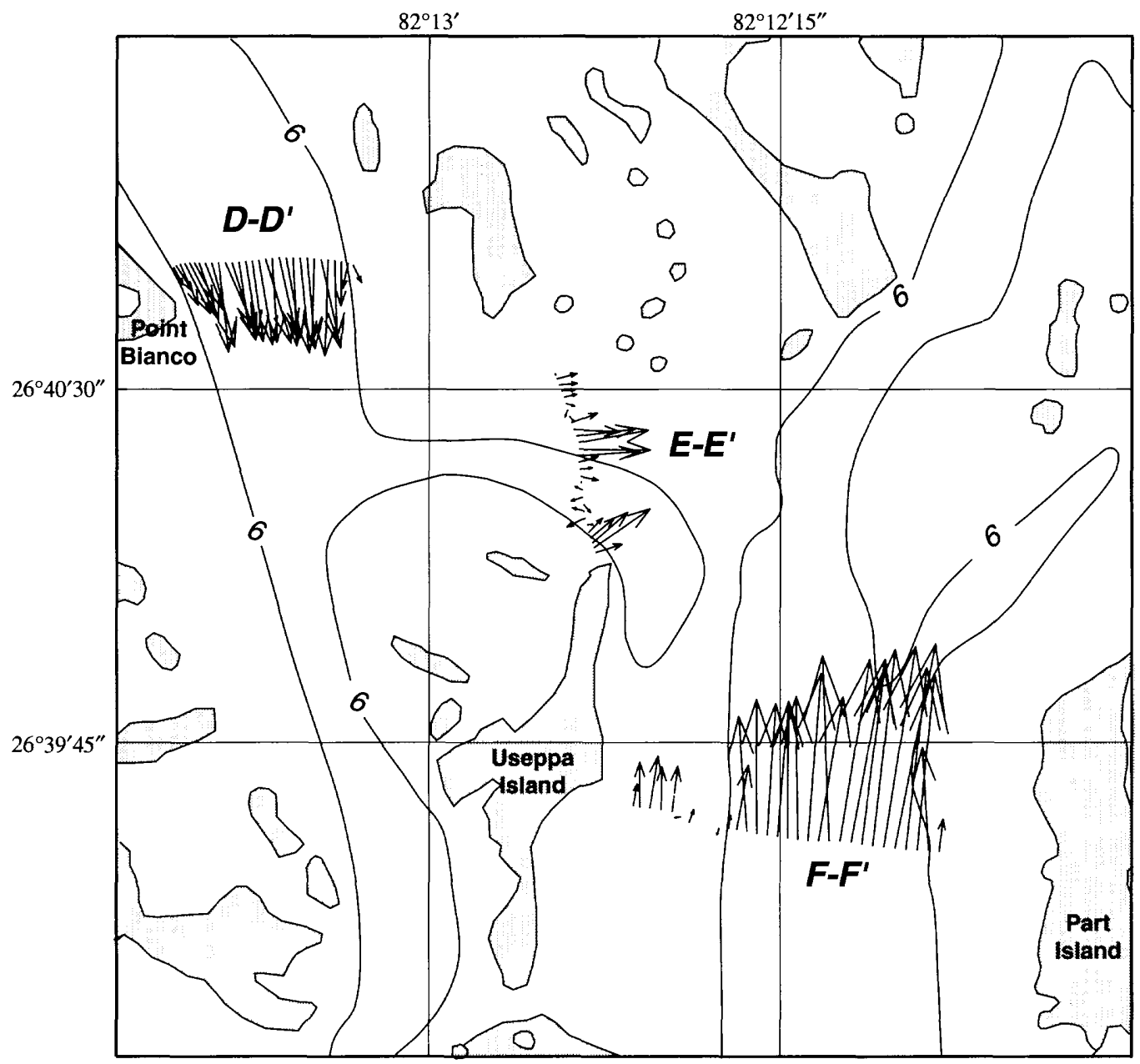

\section{EXPLANATION}

- $\quad$ REFERENCE VECTOR-- Length of vector represents 100 cubic feet per second

- 6- BATHYMETRIC CONTOUR-- Depth in feet, below mean lower low water

D-D' Measurement section MEASUREMENT SUMMARY - August 14,1996

D-D', Q = 10,600 cubic feet per second $(0959-1007)$

E-E', Q = 3,260 cubic feet per second $(1018-1028)$

$\boldsymbol{F}-\boldsymbol{F}^{\prime}, \quad Q=17,000$ cubic feet per second (1037 - 1051)

Boca $Q=-339,000$ cubic feet per second $(1443-1453)$

Grande
Pass

Figure 20. Flow patterns along measurement sections $D-D^{\prime}, E-E^{\prime}$, and $F_{-}-F^{\prime}$ in Pine Island Sound during simultaneous measurements at the mouth of Charlotte Harbor, Florida. (A) August 13, 1996 and (B) August 14, 1996. (Line of sections D-D', E-E', and F-F' shown in figure 7.)-Continued. 
flow in section F-F'. The direction of flow was usually to the north during flood flows and to the south during ebb flows at Boca Grande Pass. Flow at section F-F' was about 4 to 5 percent of the total flow at Boca Grande Pass.

Although measurements of flow were not made at Captiva Pass, flows in the northeastern part of Pine Island Sound (near section F-F') were most likely affected by flows through Captiva Pass. Goodwin (1996) included the shoals and islands that affect the flow in upper Pine Island Sound in a numerical model and accurately predicted that flood flows at Boca Grande Pass would create southerly flows in the vicinity of section D-D', easterly flows at section E-E', and northerly flows at section F-F'. The opposite directions were accurately predicted for ebb flows at Boca Grande Pass.

\section{SUMMARY}

Field measurements of flow are necessary to understand flow patterns in the Tampa Bay and the Charlotte Harbor estuarine systems and their sounds. Previously, flow patterns were studied using numerical models calibrated using limited data sets. Measurements of vertical velocity were made with a broadband acoustic Doppler current profiler under various tidal, wind, and freshwater flow conditions to understand the physical processes that control flow at the mouths of these large estuaries and sounds. These measurements support published results, which state that the driving forces of estuarine flow in Tampa Bay and Charlotte Harbor are tides and physical features, such as channels and shoals.

Both systems are typically well mixed and have relatively small freshwater inflows. Therefore, salinity stratifications seldom influence the flow patterns at the mouths of Tampa Bay and Charlotte Harbor. However, a measurement on August 16, 1995, at the mouth of Tampa Bay indicated a significant velocity stratification which could be associated with the large amount of freshwater inflow during that month. Flow measurements often exhibited bidirectional flow during changes in flow direction.

Flow at the mouth of Tampa Bay ranged from $1,260,000$ to $-954,000 \mathrm{ft}^{3} / \mathrm{s}$, with most of the flow concentrated in three main channels: Egmont Channel, Southwest Channel, and Passage Key Inlet. Flows in Anna Maria Sound ranged from 16,700 to $-13,300 \mathrm{ft}^{3} / \mathrm{s}$, with flows concentrated in the Intracoastal Waterway.
Simultaneous measurements made in $\mathrm{P}^{\top}$ ovember 1996 indicated the flow at Anna Maria Sound to be less than 1 percent of the total flow at the mouth of Tampa Bay. Comparison of measurements to numerical model results shows that the models simulated the flow patterns and strengths of flow that were measured in this study.

Flow measured at Boca Grande Pass, the mouth of Charlotte Harbor, ranged from 428,000 to $-398,000 \mathrm{ft}^{3} / \mathrm{s}$ and was distributed evenly because of the short width of the channel and the uniform crosssection depths. Many of the measurements indicated an ebb flow near Gasparilla Island, the result of a circulation eddy caused by a deep charnel on the southeast side of the island. Measurem?nts made by the USGS in 1986 were of the same magnitude as those measured in this study, and showed the uniform flow patterns seen in most of the measurements.

Flow through Pine Island Sound is restricted by the shallow waters and numerous shoals and islands. Flow data indicate that the Intracoastal Waterway carries the majority of flow into and out of the upper west side of Pine Island Sound, an ares that is influenced most by Boca Grande Pass. Measurements made east of Useppa Island suggest that a natural channel carries the majority of flow to the upper east side of Pine Island Sound and flow is influenced more strongly by Captiva Pass than by Boca Grande Pass. Flows previously simulated by a numerical model showed similar flow patterns in channels and around the shoals and islands in the northern end of Pine Island Sound.

\section{REFERENCES}

Browder, J.A., 1991, Watershed management and the importance of freshwater flow to estuaries, in Treat, S.F., and Clark, P.A., eds., Proceedings, Tampa Bay Area Scientific Information Symposicm 2, February 27-March 1, 1991: Tampa Bay Regional Planning Council, p. 7-22.

Clark, P.A., 1991, Management directions and needs for Tampa Bay tidal tributaries, in Treat, S.F., and Clark, P.A., eds., Proceedings, Tampa Bay Area Scientific Information Symposium 2, February 27-March 1, 1991: Tampa Bay Regional Planning Council, p. 497-510.

Coffin, J.E., and Fletcher, W.L., 1996, Water resources data Florida, water year 1996: U.S. Geological Survey Water-Data Report FL-96-3A, 261 p. 
Day, J.W., Jr., Hall, C.A., Kemp, W.M., and YanezArancibia, A., 1989, Estuarine Ecology: WileyInterscience, $558 \mathrm{p}$.

Galprin, B., Blumberg, A.F., and Weisberg, R.H., 1991, A time-dependant three-dimensional model of circulation in Tampa Bay, Proceedings, Tampa Bay Area Scientific Information Symposium 2, February 27 - March 1, 1991: Tampa Bay Regional Planning Council, 77-97 p.

Goodwin, C.R., 1987, Tidal-flow, circulation, and flushing changes caused by dredge and fill in Tampa Bay, Florida: U.S. Geological Survey Water-Supply Paper 2282, $88 \mathrm{p}$.

1996, Simulation of tidal-flow, circulation, and flushing of the Charlotte Harbor estuarine systems, Florida: U.S. Geological Survey Water-Resources Investigations Report 93-4153, 92 p.

Gordon, R.L., 1996, Acoustic Doppler current profiler-principles of operation, a practical primer: RD Instruments, Inc., $54 \mathrm{p}$.

Hammett, K.M., 1990, Land use, water use, streamflow characteristics, and water-quality characteristics of the Charlotte Harbor inflow area, Florida: U.S. Geological Survey Water-Supply Paper 2359-A, 64 p.

Hess, K.W., 1994, Tampa Bay oceanography project: Development and application of the numerical circulation model: National Oceanic and Atmospheric Administration Technical Report NOS OES 005, 89 p.

Johansson, J.O.R., 1991, Long-term trends of nitrogen loading, water quality, and biological indicators in Hillsborough Bay, Florida, in Treat, S.F., and Clark, P.A., eds., Proceedings, Tampa Bay Area Scientific Information Symposium 2, February 27-March 1, 1991: Tampa Bay Regional Planning Council, p. 157-176.

Levesque, V.A., and Hammett, K.M., 1997, Water transport in lower Hillsborough Bay, Florida, 19951996: U.S. Geological Survey Open-File Report 97-416, $16 \mathrm{p}$.

Rantz, S.E., and others, 1982, Measurement and computation of streamflow: Vol. 1. Measurement of stage and discharge: U.S. Geological Survey Water-Supply Paper 2175, $284 \mathrm{p}$.

Schoellhamer, D.H., 1991, Size classification of bed sediment and selection of resuspension monitoring sites in upper Tampa Bay, Florida: U.S. Geological Survey Water-Resources Investigations Report 91-4070, 23 p.

Sheng, Y.P., and Peene, S.J., 1992, Circulation and its effect on water quality: Sarasota Bay National Estuary Program - 1992 Framework for Action, $16 \mathrm{p}$.

1993, A field and modeling study of residual circulation in Sarasota Bay and Tampa Bay, Florida: Proceedings, 3rd International Conference on Coastal and Estuarine Modeling, American Society of Civil Engineers, $15 \mathrm{p}$.
Sheng, Y.P., Peene, S.J., Yassuda, E.A., Davis, J., and

Schofield, S., 1994, A field and modeling stud" on circulation and transport in Sarasota Bay, Final Report:

Gainesville, University of Florida, Coastal and Oceanographic Engineering Department, 228 p.

Simpson, M.R., and Oltmann, R.N., 1993, Dischargemeasurement system using an acoustic Dopple ${ }^{\text {r current }}$ profiler with applications to large rivers and estuaries: U.S. Geological Survey Water-Supply Paper 2395, $32 \mathrm{p}$.

Stoker, Y.E., 1992, Salinity distribution and variation with freshwater inflow and tide, and potential changes in salinity due to altered freshwater inflow in the Charlotte Harbor estuarine system, Florida: U.S. Geological Survey Water-Resources Investigations Report 92-4062, $30 \mathrm{p}$.

Stoker, Y.E., Levesque, V.A., and Woodham, W.M., 1996, The effect of discharge and water quality of th: Alafia River, Hillsborough River, and the Tampa Byrass Canal on nutrient loading to Hillsborough Bay, Florida: U.S. Geological Survey Water-Resources Investigations Report 95-4107, 69 p.

Stowers, J.F., 1991, Comprehensive planning - an important key to the future of Tampa Bay, in Treat, S.F., and Clark, P.A., eds., Proceedings, Tampa Bay Area Scientific Information Symposium 2, February 27-March 1, 1991: Tampa Bay Regional Planning Council, p. $489-496$.

U.S. Department Commerce, 1968, Climatic atlas of the United States: Environmental Science Services Administration, Environmental Data Service, June $1968,80 \mathrm{p}$.

Wiesberg, R.H., and, Williams, R.G., 1991, Initial findings of the circulation of Tampa Bay, in Treat, S.F., and Clark, P.A., eds., Proceedings, Tampa Bay Area Scientific Information Symposium 2, February 27-March 1, 1991: Tampa Bay Regional Planning Council, p. 49-66.

Yassuda, E.A., 1996, Integrated modeling of the Tampa Bay estuarine system: Gainesville, University of Florida, Coastal and Oceanographic Engineering Department, Ph.D. Dissertation, UFL/COEL-TR/113, 395 p.

Zarbock. H.W., 1991, Past, present and future freshwater inflow to Tampa Bay - effects of a changing watershed, in Treat, S.F., and Clark, P.A., eds., Proceedings, Tampa Bay Area Scientific Information Symposium 2, February 27-March 1, 1991: Tampa Bay Regional Planning Council, p. 23-33.

Zervas, C.E. (ed.), 1993, Tampa Bay oceanography project: Physical Oceanographic Synthesis, National Oceanic and Atmospheric Administration Technical Report NOS OES 002, $184 \mathrm{p}$. 
APPENDIX 
Appendix. Flow data in Tampa Bay and Charlotte Harbor, Florida, 1995-96 $\left[\mathrm{ft}^{3} / \mathrm{s}\right.$; cubic feet per second]

\begin{tabular}{|c|c|c|c|c|c|}
\hline Date & $\begin{array}{l}\text { Time } \\
\text { (EST) }\end{array}$ & $\begin{array}{c}\text { Tampa Bay at } \\
\text { Mouth } \\
\left(\mathrm{ft}^{3} / \mathrm{s}\right)\end{array}$ & $\begin{array}{c}\text { Anna Maria } \\
\text { Sound } \\
\left(\mathrm{ft}^{3} / \mathrm{s}\right)\end{array}$ & $\begin{array}{c}\text { Charlotte } \\
\text { Harbor at } \\
\text { Boca Grande } \\
\text { Pass } \\
\left(\mathrm{t}^{3} / \mathrm{s}\right)\end{array}$ & $\begin{array}{l}\text { Pine lsland } \\
\text { Snund } \\
\left(\mathrm{D}-\mathrm{B}, \begin{array}{l}\mathrm{E}, \mathrm{E}, \text { or F-F) } \\
\left(\mathrm{I}^{3} / \mathrm{s}\right)\end{array}\right.\end{array}$ \\
\hline \multirow[t]{4}{*}{ Jan. 17, 1995} & $1453-1513$ & & & $-141,000$ & \\
\hline & $1526-1547$ & & & $-34,800$ & \\
\hline & $1553-1617$ & & & 27,800 & \\
\hline & $1618-1638$ & & & 85,400 & \\
\hline \multirow{4}{*}{ Jan. 18,1995} & $1044-1108$ & & & $-295,000$ & \\
\hline & $1110-1148$ & & & & 39800 \\
\hline & $1149-1255$ & & & & 42500 \\
\hline & $1525-1543$ & & & $-111,000$ & \\
\hline \multirow{3}{*}{$\begin{array}{l}\text { Feb. 2, } 1995 \\
\text { Apr. 12, } 1995\end{array}$} & $1228-1355$ & 748,000 & & & \\
\hline & $1132-1152$ & & 16,700 & & \\
\hline & $1410-1506$ & 936,000 & & & \\
\hline \multirow[t]{14}{*}{ Apr. 19, 1995} & 0821-0917 & & & & 4,790 \\
\hline & 0958-1013 & & & $-76,000$ & \\
\hline & $1020-1033$ & & & $-167,000$ & \\
\hline & $1039-1053$ & & & $-206,000$ & \\
\hline & $1054-1106$ & & & $-236,000$ & \\
\hline & $1108-1121$ & & & $-268,000$ & \\
\hline & $1123-1133$ & & & $-287,000$ & \\
\hline & 1134.1154 & & & $-288,000$ & \\
\hline & $1146-1157$ & & & $-326,000$ & \\
\hline & $1157-1208$ & & & $-322,000$ & \\
\hline & $1209-1222$ & & & $-357,000$ & \\
\hline & $1222-1236$ & & & $-346,000$ & \\
\hline & $1236-1249$ & & & $-346,000$ & \\
\hline & $1253-1349$ & & & & $-25,800$ \\
\hline \multirow{10}{*}{ 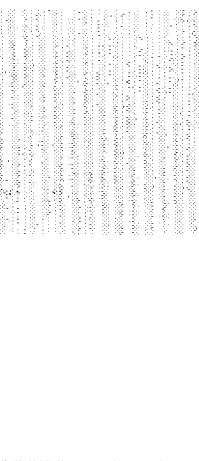 } & & & & & $-17,800$ \\
\hline & $1503-1515$ & & & $-185,000$ & \\
\hline & $1515-1525$ & & & $-165,000$ & \\
\hline & $1526-1536$ & & & $-136,000$ & \\
\hline & $1537-1547$ & & & $-109,000$ & \\
\hline & $1548-1558$ & & & $-64,700$ & \\
\hline & $1559-1609$ & & & $-35,500$ & \\
\hline & $1609-1619$ & & & $-8,680$ & \\
\hline & $1619-1630$ & & & 40,200 & \\
\hline & $1631-1641$ & & & 96,400 & \\
\hline \multirow{7}{*}{$\begin{array}{l}\text { June. } 14,1995 \\
\text { June. } 15,1995\end{array}$} & $1153-1318$ & $-492,000$ & & & \\
\hline & $1322-1445$ & 70,000 & & & \\
\hline & $0744-0908$ & $-132,000$ & & & \\
\hline & $0909-1024$ & $-759,000$ & & & \\
\hline & $1025-1147$ & $-936,000$ & & & \\
\hline & $1148-1309$ & $-780,000$ & & & \\
\hline & 1309-1418 & $-460,000$ & & & \\
\hline
\end{tabular}


Appendix. Flow data in Tampa Bay and Charlotte Harbor, Florida, 1995-96 (Continued) $\left[\mathrm{ft}^{3} / \mathrm{s}\right.$; cubic feet per second]

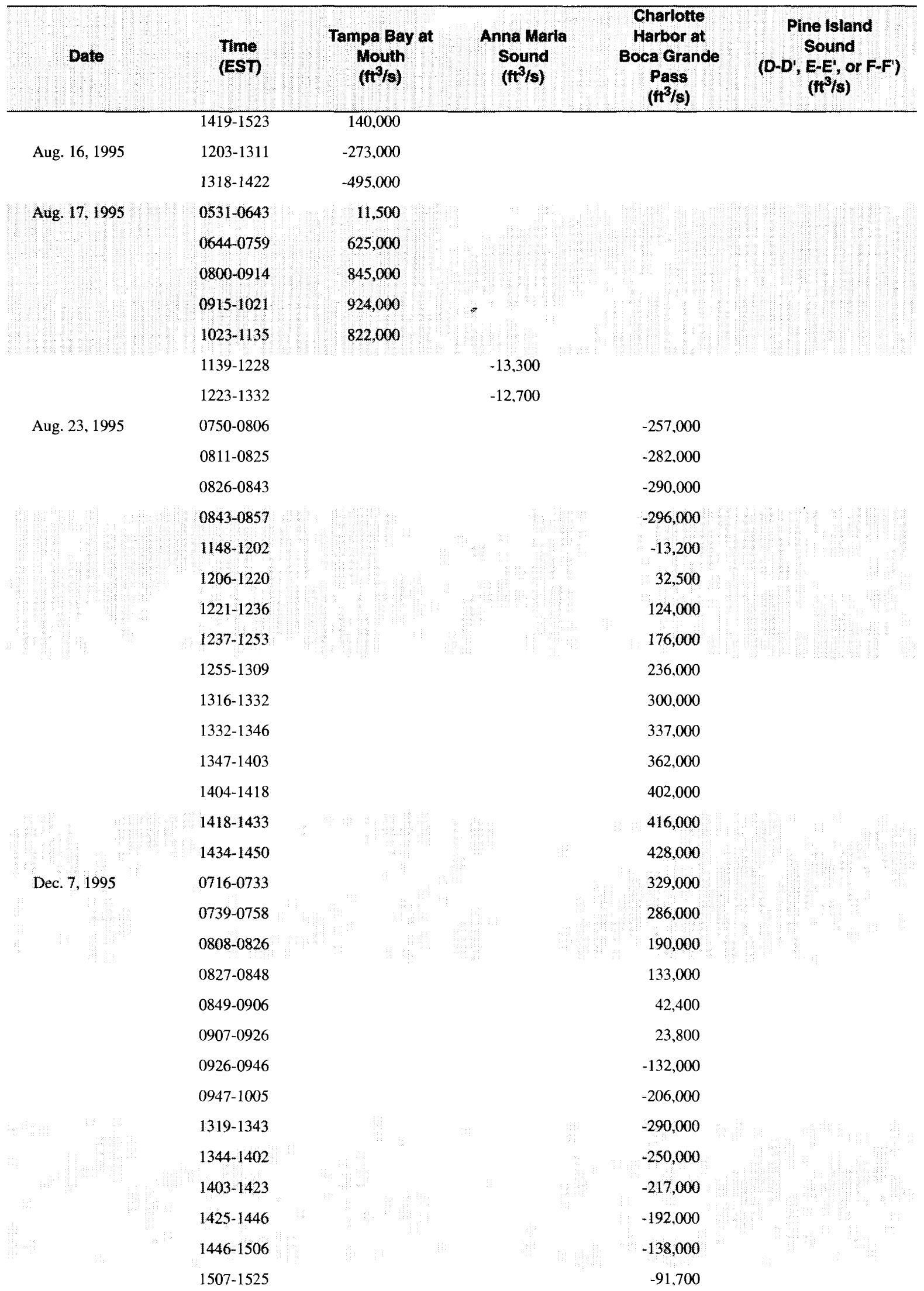


Appendix. Flow data in Tampa Bay and Charlotte Harbor, Florida, 1995-96 (Continued) $\left[\mathrm{ft}^{3} / \mathrm{s}\right.$; cubic feet per second]

\begin{tabular}{|c|c|c|c|c|c|}
\hline Date & $\begin{array}{l}\text { Time } \\
\text { (EST) }\end{array}$ & $\begin{array}{c}\text { Tampa Bay at } \\
\text { Mouth } \\
\left(\mathrm{f}^{3} / \mathrm{s}\right)\end{array}$ & $\begin{array}{c}\text { Anna Maria } \\
\text { Sound } \\
\left(\mathrm{t}^{3} / \mathrm{s}\right)\end{array}$ & $\begin{array}{c}\text { Charlotte } \\
\text { Harbor at } \\
\text { Boca Grande } \\
\text { Pass } \\
\left(\mathrm{f}^{3} / \mathrm{s}\right)\end{array}$ & $\begin{array}{l}\text { Pino Island } \\
\text { Sound } \\
\text { (D-D', E-E', or F-F) } \\
\left(\omega^{*} / \mathrm{s}\right)\end{array}$ \\
\hline \multirow{10}{*}{ Dec. 12,1995} & $1528-1545$ & & & $-48,400$ & \\
\hline & 0926-1032 & 521,000 & & & \\
\hline & $1127-1145$ & & -492 & & \\
\hline & $1147-1205$ & & $-1,410$ & & \\
\hline & $1242-1300$ & & $-3,170$ & & \\
\hline & $1301-1318$ & & $-4,260$ & & \\
\hline & $1320-1337$ & & $-3,680$ & & \\
\hline & $1340-1358$ & & $-4,680$ & & \\
\hline & $1358-1415$ & & $-3,970$ & & \\
\hline & $1419-1439$ & & $-5,850$ & & \\
\hline \multirow[t]{3}{*}{ Feb. 20, 1996} & $1214-1324$ & $-680,000$ & & & \\
\hline & $1408-1522$ & $-85,000$ & & & \\
\hline & $1549-1657$ & 651,000 & & & \\
\hline Feb. 21, 1996 & $0908-1023$ & $-16,300$ & & & \\
\hline \multirow{7}{*}{ Apr. 3,1996} & $1024-1133$ & $-675,000$ & & & \\
\hline & $1439-1457$ & & & 191,000 & \\
\hline & $1506-1519$ & & & 284,000 & \\
\hline & $1520-1542$ & & & 320,000 & \\
\hline & $1548-1605$ & & & 360,000 & \\
\hline & $1605-1626$ & & & 377,000 & \\
\hline & $1643-1816$ & & & & 14.400 \\
\hline \multirow[t]{17}{*}{ Apr. 4, 1996} & $0957-1132$ & & & & 16,100 \\
\hline & $1136-1155$ & & & $-398,000$ & \\
\hline & $1214-1229$ & & & $-324,000$ & \\
\hline & $1230-1248$ & & & $-270,000$ & \\
\hline & $1249-1306$ & & & $-231,000$ & \\
\hline & $1307-1324$ & & & $-171,000$ & \\
\hline & $1325 \cdot 1340$ & & & 126,000 & \\
\hline & $1341-1356$ & & & 74,300 & \\
\hline & $1357-1412$ & & & 32,200 & \\
\hline & $1414-1429$ & & & 47,000 & \\
\hline & $1429-1445$ & & & 104,000 & \\
\hline & $1446-1500$ & & & 185,000 & \\
\hline & $1501-1519$ & & & 243,000 & \\
\hline & $1522-1638$ & & & & 40,400 \\
\hline & $1704-1720$ & & & 423,000 & \\
\hline & $1720-1738$ & & & 418,000 & \\
\hline & $1739-1754$ & & & 421,000 & \\
\hline July. 1,1996 & $1205-1314$ & $-195,000$ & & & \\
\hline
\end{tabular}


Appendix. Flow data in Tampa Bay and Charlotte Harbor, Florida, 1995-96 (Continued) $\left[\mathrm{ft}^{3} / \mathrm{s}\right.$; cubic feet per second]

\begin{tabular}{|c|c|c|c|c|c|c|}
\hline Dato & $\begin{array}{l}\text { Time } \\
\text { (EST) }\end{array}$ & $\begin{array}{c}\text { Tampa Bay at } \\
\text { Mouth } \\
\left(\mathrm{ft}^{3} / \mathrm{s}\right)\end{array}$ & $\begin{array}{c}\text { Anna Marla } \\
\text { Sound } \\
\left(t^{3} / s\right)\end{array}$ & $\begin{array}{c}\text { Chariotte } \\
\text { Harbor at } \\
\text { Boca Grande } \\
\text { Pass } \\
\left(\mathrm{ft}^{3} / \mathbf{s}\right)\end{array}$ & $\begin{array}{l}\text { PIne Island } \\
\text { Sound } \\
\text { (D-D, E-E', or } \\
\left(\mathrm{ft}^{3} / \mathrm{s}\right)\end{array}$ & d-F' \\
\hline & $1316-1417$ & 326,000 & & & & \\
\hline & $1427-1536$ & $1,260,000$ & & & & \\
\hline \multirow[t]{4}{*}{ July. 2, 1996} & $0929-1040$ & $-954,000$ & & & & \\
\hline & $1137-1243$ & $-816,000$ & & & & \\
\hline & $1247-1349$ & $-431,000$ & & & & \\
\hline & $1349-1500$ & 408,000 & & & & \\
\hline \multirow[t]{6}{*}{ July. 9,1996} & $1409-1424$ & & & 317,000 & & \\
\hline & $1426-1441$ & & & 303,000 & & \\
\hline & $1442-1459$ & & & 287,000 & & \\
\hline & $1501-1516$ & & & 255,000 & & \\
\hline & $1516-1531$ & & & 238,000 & & \\
\hline & $1538-1654$ & & & & $-5,640$ & \\
\hline \multirow[t]{14}{*}{ July. 10, 1996} & $0745-0800$ & & & -242.000 & & \\
\hline & 0801-0817 & & & $-218,000$ & & \\
\hline & $0818-0832$ & & & $-195,000$ & & \\
\hline & 0855-0909 & & & $-114,000$ & & \\
\hline & $0910-0926$ & & & $-81,400$ & & \\
\hline & 0928-0944 & & & $-24,800$ & & \\
\hline & $0945-1000$ & & & 18,200 & & \\
\hline & $1005-1020$ & & & 120,000 & & \\
\hline & $1021-1039$ & & & 169,000 & & \\
\hline & $1103-1126$ & & & & $-1,190$ & \\
\hline & $1135-1204$ & & & & $-4,710$ & \\
\hline & $1231-1250$ & & & 381,000 & & \\
\hline & $1250-1307$ & & & 398,000 & & \\
\hline & $1312-1327$ & & & 404,000 & & \\
\hline \multirow[t]{13}{*}{ Aug. 13, 1996} & $1212-1226$ & & & $-164,000$ & & \\
\hline & $1230-1246$ & & & $-107,000$ & & \\
\hline & $1244-1313$ & & & & 15,000 & \\
\hline & $1252-1305$ & & & $-37,600$ & & \\
\hline & $1308-1323$ & & & 41,900 & & \\
\hline & $1324-1340$ & & & 90,400 & & \\
\hline & $1328-1403$ & & & & 13,100 & \\
\hline & $1343-1357$ & & & 186,000 & & \\
\hline & $1357-1414$ & & & 224,000 & & \\
\hline & $1414-1421$ & & & & 3,000 & \\
\hline & $1419-1434$ & & & 315,000 & & \\
\hline & $1424-1508$ & & & & 25 & \\
\hline & $1434-1453$ & & & 350,000 & & \\
\hline
\end{tabular}


Appendix. Flow data in Tampa Bay and Charlotte Harbor, Florida, 1995-96 (Continued) $\left[\mathrm{ft}^{3} / \mathrm{s}\right.$; cubic feet per second]

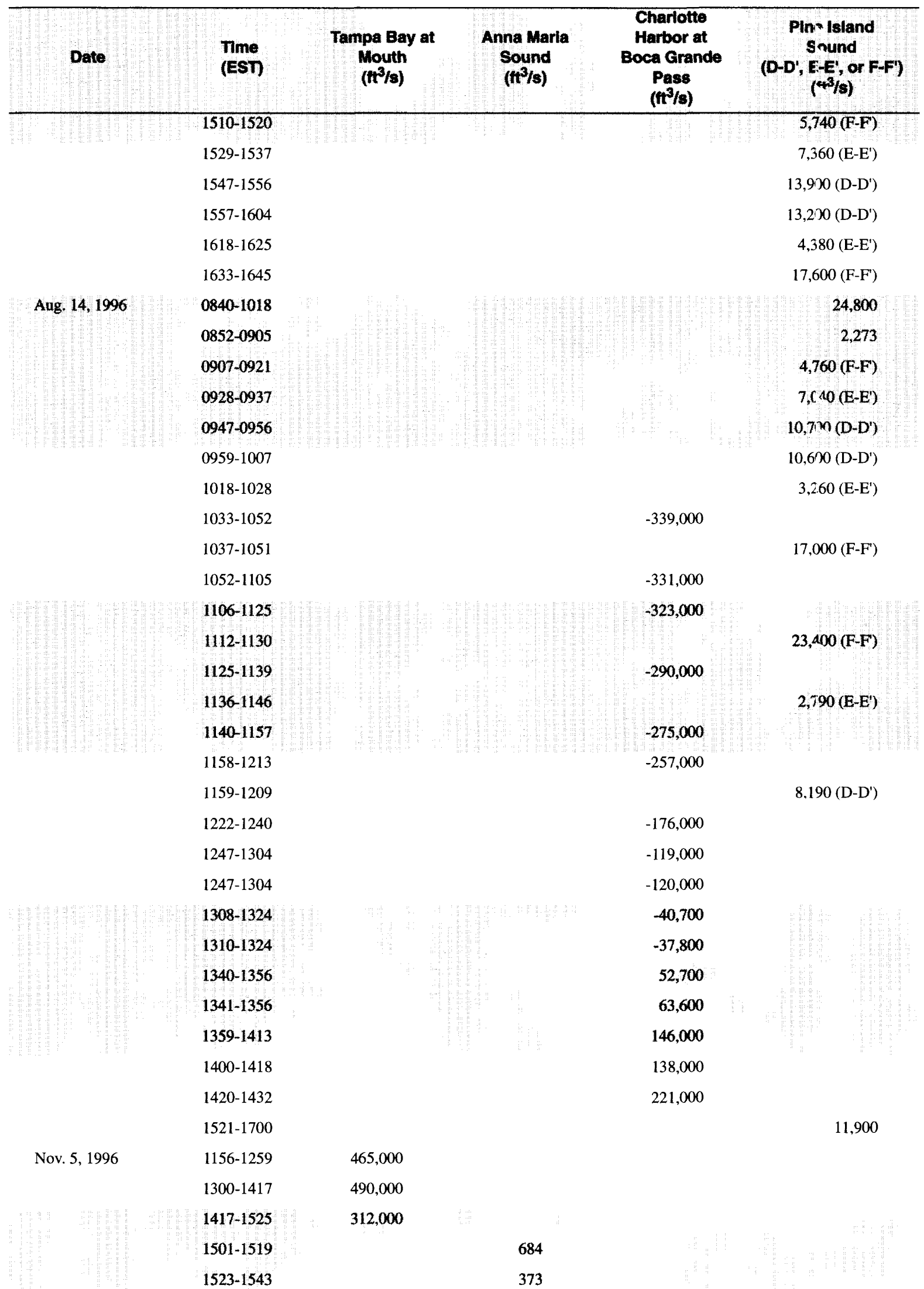


Appendix. Flow data in Tampa Bay and Charlotte Harbor, Florida, 1995-96 (Continued) $\left[\mathrm{ft}^{3} / \mathrm{s}\right.$; cubic feet per second]

\begin{tabular}{|c|c|c|c|c|c|}
\hline Date & $\begin{array}{l}\text { Time } \\
\text { (EST) }\end{array}$ & $\begin{array}{l}\text { Tampa Bay at } \\
\text { Mouth } \\
\left(\mathrm{ft}^{3} / \mathrm{s}\right)\end{array}$ & $\begin{array}{l}\text { Anna Maria } \\
\text { Sound } \\
\left(\mathrm{ft}^{3} / \mathrm{s}\right)\end{array}$ & $\begin{array}{c}\text { Charlotte } \\
\text { Harbor at } \\
\text { Boca Grande } \\
\text { Pass } \\
\left(\mathrm{tt}^{3} / \mathrm{s}\right)\end{array}$ & $\begin{array}{l}\text { Pine lsland } \\
\text { Sound } \\
\text { (D-D', E-E', or F-F') } \\
\left(\mathrm{H}^{3} / \mathrm{s}\right)\end{array}$ \\
\hline \multirow{21}{*}{ Nov. 6,1996} & $1526-1635$ & $-118,000$ & & & \\
\hline & 0836-0941 & $-573,000$ & & & \\
\hline & 0858-0913 & & 300 & & \\
\hline & 0913-0928 & & -773 & & \\
\hline & 0928-0943 & & -276 & & \\
\hline & 0942-1045 & $-198,000$ & & & \\
\hline & 0944-1002 & & -183 & & \\
\hline & $1003-1020$ & & 239 & & \\
\hline & $1021-1035$ & & 1,170 & & \\
\hline & $1036-1052$ & & 1,570 & & \\
\hline & $1046-1148$ & 72,300 & & & \\
\hline & $1054-1107$ & & 1,340 & & \\
\hline & $1127-1144$ & & 1,910 & & \\
\hline & $1148-1252$ & 519,000 & & & \\
\hline & $1150-1205$ & & 1,970 & & \\
\hline & $1206-1220$ & & 2,070 & & \\
\hline & $1223-1238$ & & 1.530 & & \\
\hline & $1315-1421$ & 716,000 & & & \\
\hline & $1316-1428$ & 672,000 & & & \\
\hline & $1433-1537$ & 558,000 & & & \\
\hline & $1436-1541$ & 511,000 & & & \\
\hline \multirow[t]{13}{*}{ Nov. 25,1996} & $1220-1236$ & & & $-325,000$ & \\
\hline & $1237-1251$ & & & $-313,000$ & \\
\hline & $1251-1303$ & & & $-301,000$ & \\
\hline & $1303-1315$ & & & $-277,000$ & \\
\hline & $1315-1327$ & & & $-269,000$ & \\
\hline & $1403-1411$ & & & & $19,700\left(D^{-D^{\prime}}\right)$ \\
\hline & $1422-1428$ & & & & $8,660\left(\mathrm{E}^{-\mathrm{E}^{\prime}}\right)$ \\
\hline & $1436-1448$ & & & & $25,000\left(\mathrm{~F}-\mathrm{F}^{\prime}\right)$ \\
\hline & $1449-1501$ & & & & $23,600\left(F-F^{\prime}\right)$ \\
\hline & $1507-1514$ & & & & $10,341\left(E^{-} E^{\prime}\right)$ \\
\hline & $1521-1529$ & & & & 18,400 (D-D') \\
\hline & $1548-1600$ & & & 34,200 & \\
\hline & $1600-1613$ & & & 42,000 & \\
\hline
\end{tabular}


